\title{
National Green Building Standard Analysis
}

NAHB Research Center 


\title{
This report received minimal editorial review at NREL.
}

\begin{abstract}
NOTICE
This report was prepared as an account of work sponsored by an agency of the United States government. Neither the United States government nor any agency thereof, nor any of their employees, subcontractors, or affiliated partners makes any warranty, express or implied, or assumes any legal liability or responsibility for the accuracy, completeness, or usefulness of any information, apparatus, product, or process disclosed, or represents that its use would not infringe privately owned rights. Reference herein to any specific commercial product, process, or service by trade name, trademark, manufacturer, or otherwise does not necessarily constitute or imply its endorsement, recommendation, or favoring by the United States government or any agency thereof. The views and opinions of authors expressed herein do not necessarily state or reflect those of the United States government or any agency thereof.
\end{abstract}

Available electronically at http://www.osti.gov/bridge

Available for a processing fee to U.S. Department of Energy and its contractors, in paper, from:

U.S. Department of Energy

Office of Scientific and Technical Information

P.O. Box 62

Oak Ridge, TN 37831-0062

phone: 865.576 .8401

fax: 865.576.5728

email: mailto:reports@adonis.osti.gov

Available for sale to the public, in paper, from:

U.S. Department of Commerce

National Technical Information Service

5285 Port Royal Road

Springfield, VA 22161

phone: 800.553 .6847

fax: 703.605.6900

email: orders@ntis.fedworld.gov

online ordering: http://www.ntis.gov/ordering.htm

Printed on paper containing at least $50 \%$ wastepaper, including $20 \%$ postconsumer waste 


\title{
National Green Building Standard Analysis
}

\author{
Prepared for: \\ Building America \\ Building Technologies Program \\ Office of Energy Efficiency and Renewable Energy \\ U.S. Department of Energy
}

\author{
Prepared by: \\ NAHB Research Center \\ 400 Prince George's Boulevard \\ Upper Marlboro, MD 20774
}

June 2012 
[This page left blank] 


\section{Contents}

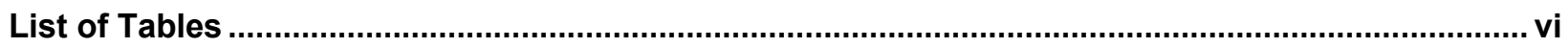

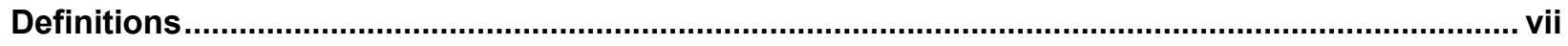

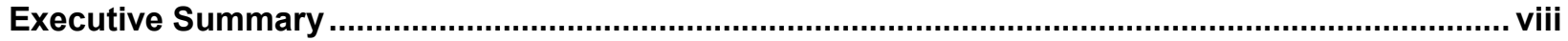

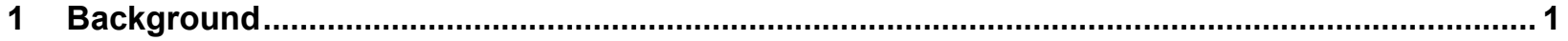

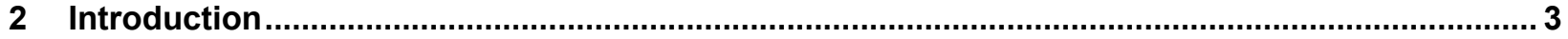

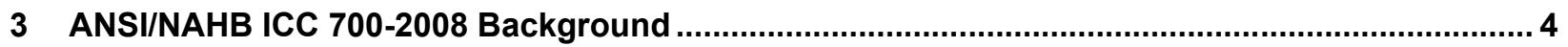

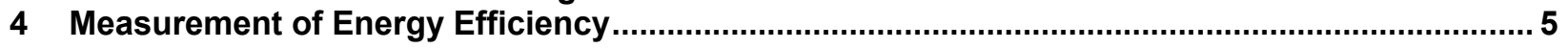

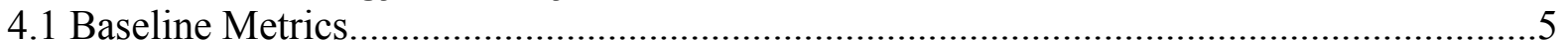

4.2 Modeling Software and Analysis Methodology ..........................................................

4.3 Results: Benchmark Source Energy Savings for the 40\%-50\% Case .............................11

4.4 Energy Efficiency Point Value Recommendations......................................................15

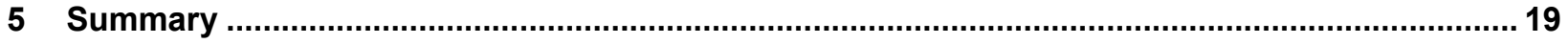

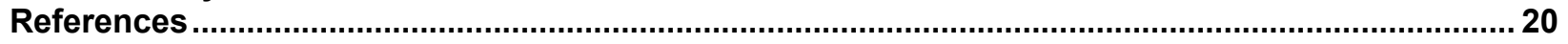

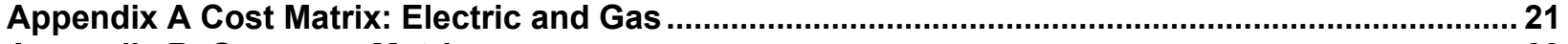

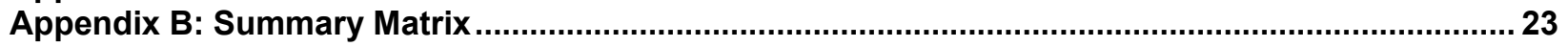




\section{List of Tables}

Table 1. Multiyear Energy Savings* Goals for Existing Homes ..................................................... 1

Table 2. Multiyear Energy Savings* Goals for New Homes .............................................................. 2

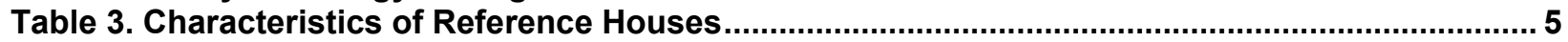

Table 4. Foundation Types Attributed to Reference Houses ............................................................ 5

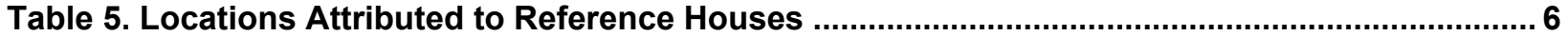

Table 6. Comparison of RESNET and BA Energy Usage Formulas .............................................. 7

Table 7. Comparison of RESNET and BA Energy Usage ............................................................. 8

Table 8. Reference House Features Specified by the 2009 IECC ...................................................... 9

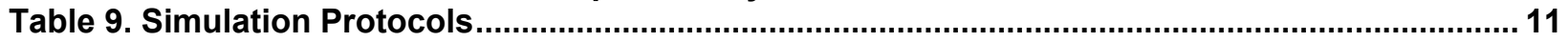

Table 10. Benchmark, Reference, and $\mathbf{4 0} \%-50 \%$ Source Energy Savings Case for Climate

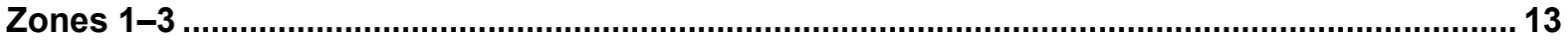

Table 11. Benchmark, Reference, and $\mathbf{4 0} \% \mathbf{- 5 0 \%}$ Source Energy Savings Case for Climate

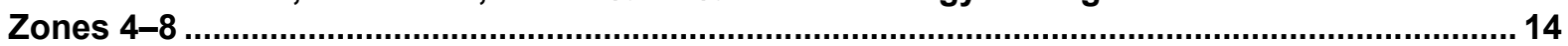

Table 12. Initial 40\%-50\% Case Practices Analysis ................................................................. 15

Table 13. Initial Matrix of Proposed Points With Comparison to ANSI/NAHB ICC 700-2008 Points, 1 of 2

Table 14. Initial Matrix of Proposed Points With Comparison to ANSI/NAHB ICC 700-2008 Points, 2 of 2

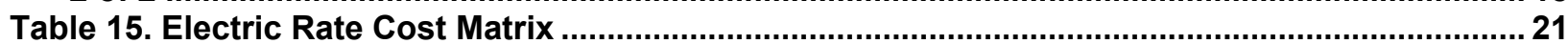

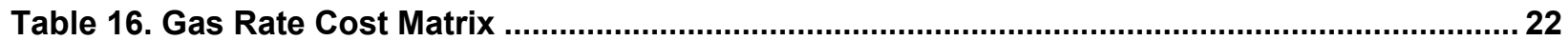

Table 17. Initial Normalized Percent Savings for Electric Fuel and Simulation Location .................23

Table 18. Initial Normalized Percent Savings for Gas Fuel and Simulation Location........................ 24 


\section{Definitions}

ANSI/NAHB ICC National Green Building Standard 700-2008

ANSI

BA

EIA

IECC

NAHB

NREL

SEF

RESNET
American National Standards Institute

DOE's Building America Research Program

U.S. Energy Information Administration

International Energy Conservation Code

National Association of Home Builders

National Renewable Energy Laboratory

Solar Energy Factor

Residential Energy Services Network 


\section{Executive Summary}

The U.S. Department of Energy's Building America (BA) Program is a research and development program to improve the energy performance of new and existing homes. The ultimate BA goal is to achieve examples of cost-effective, energy-efficient solutions for all U.S. climate zones. This goal will be met using a whole-house system engineering approach and by uniting segments of the industry that traditionally work independently of one another, including architects, engineers, builders, remodelers, trade contractors, manufacturers, material suppliers, community planners, and mortgage lenders.

One example of this type of collaboration is the National Green Building Standard (NGBS) (ANSI/NAHB ICC 700-2008, 2009). ICC 700 was developed by a balanced consensus committee of general interest, producers, and users and approved by the American National Standards Institute (ANSI) as an American National Standard on January 29, 2009. Periodic maintenance of an ANSI standard by review of the entire document and action to revise or reaffirm it on a schedule not to exceed five years is required by ANSI. In compliance, a consensus group has once again been formed and NGBS is currently being reviewed to comply with the periodic maintenance requirement of an ANSI standard.

There are two important considerations for the energy efficiency chapter update process. The first is the methodology for energy savings and the second is the new baseline for energy savings. The updated energy chapter is proposed to use a whole-house energy savings methodology and therefore further align with the BA methodology. In addition, the newly proposed baseline for energy savings is the 2009 International Energy Conservation Code (IECC). Therefore, in order to reach any level of certification, the building's performance must exceed that of a similar building constructed to the 2009 IECC. Effectively, this results in the lowest level of certification, Bronze in the energy efficiency chapter, aligning with the 2012 IECC. The savings for the other three levels, Silver, Gold, and Emerald, are even higher. The recommendations in this report are made with the goal of making the NGBS rating levels consistent with IECC 2012 and BA goals. Actual savings levels will depend on final decisions made by the consensus committee.

This report details the proposed point structure for the prescriptive approach of the energy efficiency chapter of the NGBS update. This proposed point structure was developed with support from the BA house design and simulation protocols. The source energy was calculated for both the reference home and the proposed house in each specific climate. This analysis also compared the simulated energy performance of a home designed to meet the revised NGBS Chapter 7 at the Gold level with reference to the 2010 BA Benchmark using the BA House Simulation Protocols. The results of modeling various houses in multiple climate zones indicate that the range of energy savings for the designs is $40 \%-50 \%$ for the Gold level. This range aligns well with BA program energy savings goals of $30 \%-50 \%$ whole-house energy savings. 


\section{Background}

The U.S. Department of Energy's Building America (BA) Program is a research and development program to improve the energy performance of new and existing homes. The ultimate BA goal is to achieve examples of cost-effective, energy-efficient solutions for all U.S. climate zones. This goal will be met using a whole-house system engineering approach and by uniting segments of the industry that traditionally work independently of one another, including architects, engineers, builders, remodelers, trade contractors, manufacturers, material suppliers, community planners, and mortgage lenders.

One example of this type of collaboration is the National Green Building Standard (NGBS) (ANSI/NAHB ICC 700-2008, 2009, NAHB Research Center, 2009). ICC 700 was developed by a balanced consensus committee of general interest, producers, and users and approved by the American National Standards Institute (ANSI) as an American National Standard on January 29, 2009. Periodic maintenance of an ANSI standard by review of the entire document and action to revise or reaffirm it on a schedule not to exceed five years is required by ANSI. In compliance, a consensus group has once again been formed and the NGBS is currently being reviewed to comply with the periodic maintenance requirement of an ANSI standard.

As part of the periodic maintenance the energy efficiency portion of the ICC 700, Chapter 7 Energy Efficiency, is being updated. There are two important considerations for the energy efficiency chapter update process. The first is the methodology for energy savings and the second is the new baseline for energy savings. The updated energy chapter is proposed to use a whole-house energy savings methodology and therefore further align with the BA methodology. In addition, the newly proposed baseline for energy savings is the 2009 International Energy Conservation Code (IECC) (IECC, 2009). Therefore, in order to reach any level of certification, the building's performance must exceed that of a similar building constructed to the 2009 IECC. Effectively, this results in the lowest level of certification, Bronze in the energy efficiency chapter, aligning with the 2012 IECC (IECC, 2012). The savings for the other three levels, Silver, Gold, and Emerald, are even higher. The recommendations in this report are made with the goal of making the NGBS rating levels consistent with IECC 2012 and BA goals (see Tables 1 and 2). Actual savings levels will depend on final decisions made by the consensus committee.

Table 1. Multiyear Energy Savings* Goals for Existing Homes

\begin{tabular}{c|c|c|c}
\hline Energy Savings & $\begin{array}{c}\text { Mixed/Hot-Dry } \\
\text { and Marine }\end{array}$ & $\begin{array}{c}\text { Mixed-Humid } \\
\text { and Hot-Humid }\end{array}$ & $\begin{array}{c}\text { Cold, Very Cold, } \\
\text { and Subarctic }\end{array}$ \\
\hline $\begin{array}{c}\text { Current "Best in } \\
\text { Class" (15\% or above) }\end{array}$ & 2011 & 2011 & 2011 \\
\hline $\mathbf{3 0 \%}$ & 2012 & 2013 & 2014 \\
\hline $\mathbf{5 0 \%}$ & 2015 & 2016 & 2017 \\
\hline *Savings based on the IECC 2009 & \multicolumn{4}{l}{} \\
\hline
\end{tabular}


Table 2. Multiyear Energy Savings* Goals for New Homes

\begin{tabular}{c|c|c|c}
\hline Energy Savings & $\begin{array}{c}\text { Mixed/Hot-Dry } \\
\text { and Marine }\end{array}$ & $\begin{array}{c}\text { Mixed-Humid } \\
\text { and Hot-Humid }\end{array}$ & $\begin{array}{c}\text { Cold, Very Cold, } \\
\text { and Subarctic }\end{array}$ \\
\hline $\begin{array}{c}\text { Current "Best in } \\
\text { Class" (20\% or above) }\end{array}$ & 2010 & 2011 & 2011 \\
\hline $\mathbf{3 0 \%}$ & 2011 & 2012 & 2013 \\
\hline $\mathbf{5 0 \%}$ & 2014 & 2015 & 2016 \\
\hline *Savings based on the IECC 2009 & \multicolumn{3}{|l}{} \\
\hline
\end{tabular}

The ICC 700 and BA link building science research and actual energy efficiency improvements implemented by builders and remodelers based on a whole-house systems approach. This relationship demonstrates that homes can be designed and constructed according to the principles developed by BA on a larger scale. The collaboration introduces builders and remodelers to certification programs including Builders Challenge through the dual certification process, and provides materials for the marketing and sales activities of high performance builders. 


\section{Introduction}

NBGS is a system of rating the sustainability of the siting, construction practices and products, and expected performance of a residential building. Point thresholds determine the project's compliance with the criteria that support progressively higher rating levels: Bronze, Silver, Gold and Emerald. By the ICC 700-2008, practices defined in the areas of site development, resource efficiency, energy efficiency, water efficiency, indoor environmental quality, and operation, maintenance, and education earn points toward an overall green rating level.

Chapter 7 of the ICC 700-2008 covers the energy efficiency (EE) of residential buildings. To be useful to a broad spectrum of builders, the ICC 700-2008 allows a choice between a performance and a prescriptive approach to achieve the Energy Efficiency Chapter 7 point thresholds for the Bronze, Silver, and Gold levels. The highest level rating (Emerald), requires use of the performance compliance approach.

The proposed revisions to Chapter 7, Energy Efficiency, of the ICC 700-2008 are the subject of this analysis; specifically, the correlation of the points for individual prescriptive practices relative to the expected energy savings from that practice. 


\title{
3 ANSI/NAHB ICC 700-2008 Background
}

Chapter 7 of the 2008 version of the ICC 700 Standard (ANSI/NAHB ICC 700-2008, 2009) contains five sections titled:

\author{
701 - Minimum Energy Efficiency Requirements \\ 702 - Performance Path \\ 703 - Prescriptive Path \\ 704 - Additional Practices \\ 705 - Innovative Practices
}

A standards Consensus Committee was convened in 2011 to update the 2008 version of the ICC 700. As part of this process, task groups were developed to address specific topics and make recommendations to the Consensus Committee. Task Group 5 was assigned to Chapter 7 review. A primary goal of Task Group 5 was to recommend changes to eliminate incongruities between various sections of Chapter 7. In particular, in practice it was recognized that the points available through the Prescriptive Path (Section 703) were often inconsistent with the points available from the Performance Path (Section 702). To avoid redundancies, Task Group 5 proposed that some of Section 704, Additional Practices points, be moved to the Prescriptive Path, Section 703, thereby aligning the chapter's rating system for both compliance path approaches more closely with the effective whole-house energy savings results. A goal of the task group was to align the Prescriptive and Performance Path practices' point values with the practices' actual contribution to a building's energy efficiency.

Furthermore, Task Group 5 proposed to the Consensus Committee (which has since approved it) that a building meet the minimum requirements of the 2009 IECC. Because some of the provisions in the 2009 IECC had previously been awarded points in the ICC 700-2008, these incongruities had to be resolved in the updates to the standard through recommendations to the Consensus Committee. The task group also recommended redefined levels of merit within the ICC 700 Standard as 15\%, 30\%, 40\%, and 50\% better "whole-house" energy performance than the 2009 IECC. (ICC 700-2008 levels were 15\%-60\% over the 2006 IECC.)

Working in parallel with the recommendations proposed by Task Group 5, this report details the effort to review the Prescriptive Path approach (Section 703) of Chapter 7 and recommend a point structure that will support the stated energy savings thresholds that will be ultimately recommended to the Consensus Committee for approval. 


\section{Measurement of Energy Efficiency}

\subsection{Baseline Metrics}

In order to establish a baseline metric consistent with the 2009 IECC, a standard house design was developed from statistics in annual builder surveys compiled by the NAHB Research Center. The standard house design was used in the energy simulations undertaken to support point recommendations in Section 703 of Chapter 7. This standard house design was modeled on various foundations, again selected from statistical data by region. Climate zones and cities within the zones where each of these designs was modeled, were selected based on $\mathrm{BA}^{1}$ and other resources. ${ }^{2}$ The climate zones extend from 1 through 8 (covering the United States) and the selected locations include moist and dry climates in each zone, as appropriate. Thirteen cities were selected to represent the eight climate zones in the country. Table 3 and Table 4 cover the house design details; Table 5 covers the location information used in the energy simulations.

Table 3. Characteristics of Reference Houses

\begin{tabular}{c|c}
\hline House Characteristic & Dimension \\
\hline Above-Grade Conditioned Area & $2,401 \mathrm{ft}^{2}$ \\
\hline First Floor Area & $1,801 \mathrm{ft}^{2}$ \\
\hline Second Floor Area & $600 \mathrm{ft}^{2}$ \\
\hline Slab/Basement Area & $1,801 \mathrm{ft}^{2}$ \\
\hline Slab/Basement Perimeter & $196 \mathrm{ft}$ \\
\hline First Floor Height & $9.0 \mathrm{ft}$ \\
\hline Second Floor Height & $8.5 \mathrm{ft}$ \\
\hline Basement Height & $8.0 \mathrm{ft}$ \\
\hline Basement Wall Above Grade (2 ft Above Grade) & $392 \mathrm{ft}^{2}$ \\
\hline Window Area (Slab Foundation) & $360 \mathrm{ft}^{2}$ \\
\hline Window Area (Basement Foundation) & $420 \mathrm{ft}^{2}$ \\
\hline Above-Grade Wall Area & $2,597 \mathrm{ft}^{2}$ \\
\hline Basement Wall Area & $1,568 \mathrm{ft}^{2}$ \\
\hline Number of Bedrooms & 3 \\
\hline Number of Bathrooms & 2.5 \\
\hline Roof Overhang & $1 \mathrm{ft}$ \\
\hline
\end{tabular}

Table 4. Foundation Types Attributed to Reference Houses

\begin{tabular}{c|c|c|c|c|c|c|c|c|c|c|c|c|c}
\hline Climate Zone & 1A & 2A & 2B & 3A & 3B & 4A & 4C & 5A & 5B & 6A & 6B & 7 & 8 \\
\hline \multicolumn{10}{c|}{ Foundation Type } \\
\hline Slab & $\mathrm{x}$ & $\mathrm{x}$ & $\mathrm{x}$ & $\mathrm{x}$ & $\mathrm{x}$ & $\mathrm{x}$ & & & & & & & $\mathrm{x}$ \\
\hline Vented Crawlspace & & & & $\mathrm{x}$ & & & $\mathrm{x}$ & & & & & & \\
\hline Inground Basement & & & & & & $\mathrm{x}$ & & $\mathrm{x}$ & $\mathrm{x}$ & $\mathrm{x}$ & $\mathrm{x}$ & $\mathrm{x}$ & \\
\hline
\end{tabular}

\footnotetext{
${ }^{1} \mathrm{http} / /$ www1.eere.energy.gov/buildings/challenge/technical_resources.html

${ }^{2}$ Technical Support Document: 50\% Energy Savings for Smāll Office Buildings, Liu, B., et. Al. PNNL-19341, April 2010
} 
Table 5. Locations Attributed to Reference Houses

\begin{tabular}{c|c|c|c}
\hline Zone/Description & City, State & $\begin{array}{c}\text { HDD } \\
(\mathbf{6 5})\end{array}$ & $\begin{array}{c}\text { CDD } \\
(\mathbf{6 5})\end{array}$ \\
\hline 1A - Hot, Humid & Miami, Florida & 149 & 4,361 \\
\hline 2A - Hot, Humid & Houston, Texas & 1,525 & 2,893 \\
\hline 2B - Hot, Dry & Phoenix, Arizona & 1,125 & 4,189 \\
\hline 3A - Hot, Humid & Atlanta, Georgia & 2,827 & 1,810 \\
\hline 3B - Hot, Dry & Las Vegas, Nevada & 2,239 & 3,214 \\
\hline 4A - Mixed, Humid & Baltimore, Maryland & 4,720 & 1,147 \\
\hline 4C - Marine & Seattle, Washington & 4,797 & 173 \\
\hline 5A - Cold, Humid & Chicago, Illinois & 6,498 & 830 \\
\hline 5B - Cold, Dry & Denver, Colorado & 6,128 & 696 \\
\hline 6A - Cold, Humid & Minneapolis, Minnesota & 7,876 & 699 \\
\hline 6B - Cold, Dry & Helena, Montana & 7,975 & 277 \\
\hline 7 - Very Cold & Duluth, Minnesota & 9,724 & 189 \\
\hline 8 - Extreme Cold & Fairbanks, Alaska & 13,980 & 74 \\
\hline
\end{tabular}

The 2009 IECC is the baseline energy code above which the energy efficiency of the pending version of ICC 700 was gauged based on the anticipated timing of the updated ICC 700 release in 2012. In order to perform representative simulations in BEopt ${ }^{3}$ the energy simulation software used by BA, a reference house was defined. The reference house represents minimum prescriptive compliance with the 2009 IECC, Section 402.1.

The BA and the Residential Energy Services Network (RESNET) ${ }^{4}$ guidelines are used as a basis for the analysis (Hendron, R; Engebrecht, C, 2010). Both of these approaches to energy savings, along with the software that is used to model house energy use, are important to provide better, more detailed analysis for the ICC 700, Chapter 7. Both are needed because the point system development for the ICC 700, as well as practical, commercially available modeling tools to verify compliance within the Standard, require use of multiple approaches. Both of these approaches are integrated in this analysis to provide the basis for the development of the point system in the Energy Efficiency chapter of the ICC 700.

BA and RESNET apply different procedures to simulate plug, appliance, and miscellaneous electric loads in houses, and these organizations' simulation protocols back the two predominant residential energy simulation software programs. RESNET procedures for estimates of lighting and appliance energy ${ }^{5}$ were reflected in the reference house used in this analysis so that wholehouse simulation results might be similar from the two software programs when practices in the

\footnotetext{
${ }^{3}$ NREL developed the BEopt, version 1.1 (Building Energy Optimization) software to provide capabilities to evaluate residential building designs and identify cost-optimal efficiency packages at various levels of whole-house energy savings along the path to zero net energy. http://beopt.nrel.gov/

${ }^{4}$ Residential Energy Services Network, providers of energy audits and the software, REMRate, software that produces a HERs Index that is used to determine ENERGY STAR compliance.

${ }^{5}$ RESNET Proposed Standards Revision, Date: 01/15/10 (as modified by Aux Energy Sub: 07/16/10) Amendment \#2011 - As modified following resolution of public comments: April 11, 2011, Lighting, Appliance and Miscellaneous Energy Usage Profiles
} 
ICC 700 are applied. ${ }^{6}$ Table 6 and Table 7 highlight the differences between RESNET and BA energy use estimates.

Table 6. Comparison of RESNET and BA Energy Usage Formulas

\begin{tabular}{|c|c|c|c|c|}
\hline Appliance/Device & $\begin{array}{l}\text { RESNET } \\
\text { Estimate }^{1}\end{array}$ & $\begin{array}{c}\text { BA } \\
\text { Benchmark Estimate }^{2}\end{array}$ & $\begin{array}{l}\text { RESNET } \\
\text { Use } \\
\text { Estimate }^{10} \\
\end{array}$ & $\begin{array}{c}\text { Benchmark } \\
\text { Use } \\
\text { Estimate }^{10} \\
\end{array}$ \\
\hline Interior Lighting & $455+\left(0.80 * \mathrm{CFA}^{3}\right)$ & & 2,376 & \\
\hline $\begin{array}{l}\text { Interior Lighting } \\
\text { (Hardwired) }\end{array}$ & & $0.8 *\left(\mathrm{FFA}^{4 *} 0.542+334\right)$ & & 1,308 \\
\hline $\begin{array}{c}\text { Interior Plug-In } \\
\text { Lighting }\end{array}$ & & $0.2 *\left(\mathrm{FFA}^{*} 0.542+334\right)$ & & 327 \\
\hline Exterior Lighting & $100+(0.05 * \mathrm{CFA})$ & FFA $* 0.145$ & 220 & 348 \\
\hline Garage Lighting & 100 & $\left(\mathrm{GA}^{5 * 0.08)+8.0}\right.$ & 100 & 40 \\
\hline Refrigerator & $637+\left(18 * \mathrm{~N}_{\mathrm{br}}^{6}\right)$ & 434 & 691 & 434 \\
\hline Electric Range/Oven & $331+\left(39 * \mathrm{~N}_{\mathrm{br}}\right)$ & $250+\left(83 * \mathrm{~N}_{\mathrm{br}}\right)$ & 448 & 499 \\
\hline Gas Range/Oven (Gas) & $22.6+\left(2.7 * \mathrm{~N}_{\mathrm{br}}\right)$ & $14.3+\left(4.8 * \mathrm{~N}_{\mathrm{br}}\right)$ & 31 & 29 \\
\hline $\begin{array}{c}\text { Gas Range/Oven } \\
\text { (Electric) }\end{array}$ & $22.6+\left(2.7 * \mathrm{~N}_{\mathrm{br}}\right)$ & $40+\left(13.3 * \mathrm{~N}_{\mathrm{br}}\right)$ & 31 & 80 \\
\hline Dishwasher & $78+\left(31 * \mathrm{~N}_{\mathrm{br}}\right)$ & $87.6+\left(29.2 * \mathrm{~N}_{\mathrm{br}}\right)$ & 171 & 175 \\
\hline Clothes Washer & $38+\left(10.0 * \mathrm{~N}_{\mathrm{br}}\right)$ & $38.8+\left(12.9 * \mathrm{~N}_{\mathrm{br}}\right)$ & 78 & 68 \\
\hline Electric Clothes Dryer & $524+\left(149 * \mathrm{~N}_{\mathrm{br}}\right)$ & $538.2+\left(179.4 * \mathrm{~N}_{\mathrm{br}}\right)$ & 971 & 1,076 \\
\hline $\begin{array}{c}\begin{array}{c}\text { Gas Clothes Dryer } \\
\text { (Gas) }\end{array} \\
\end{array}$ & $18.8+\left(5.3 * \mathrm{~N}_{\mathrm{br}}\right)$ & $19.5+\left(6.5 * \mathrm{~N}_{\mathrm{br}}\right)$ & 35 & 39 \\
\hline $\begin{array}{c}\text { Gas Clothes Dryer } \\
\text { (Electric) }\end{array}$ & $41+\left(11.7 * \mathrm{~N}_{\mathrm{br}}\right)$ & $43+\left(14.3 * \mathrm{~N}_{\mathrm{br}}\right)$ & 76 & 86 \\
\hline Televisions & $413+\left(69 * N_{b r}\right)$ & & 620 & 0 \\
\hline $\begin{array}{l}\text { Miscellaneous } \\
\text { (Electric) }^{7}\end{array}$ & $0.91 * \mathrm{CFA}$ & $\begin{array}{c}1703+\left(266 * \mathrm{~N}_{\mathrm{br}}\right)+(0.454 * \\
\text { FFA })\end{array}$ & 2,185 & 3,591 \\
\hline $\begin{array}{l}\text { Miscellaneous } \\
\text { (Electric) }^{8}\end{array}$ & $0.91 * \mathrm{CFA}$ & $\begin{array}{c}1595+\left(248 * \mathrm{~N}_{\mathrm{br}}\right)+(0.426 * \\
\text { FFA })\end{array}$ & 2,185 & 3,362 \\
\hline Miscellaneous (Gas) $^{8}$ & & $\begin{array}{c}3.7+\left(0.6 * \mathrm{~N}_{\mathrm{br}}\right)+(0.001 * \mathrm{FF} \\
\mathrm{A})\end{array}$ & 0.0 & 7.9 \\
\hline $\begin{array}{c}\text { Ventilation Fan } \\
\text { Energy }^{9} \\
\end{array}$ & $\begin{array}{c}(0.03942 * \mathrm{CFA})+ \\
\left(29.565 * \mathrm{~N}_{\mathrm{br}}\right)\end{array}$ & $0.5 \mathrm{~W} / \mathrm{cfm}$ & 212 & 237 \\
\hline 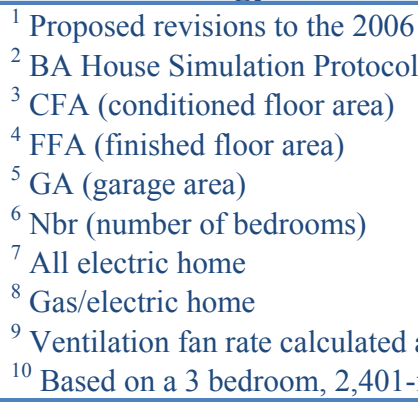 & $\begin{array}{l}4 \mathrm{cfm} \\
\text { home }(\mathrm{CFA}=\mathrm{FFA}) \text { with }\end{array}$ & $\begin{array}{l}\text { Iome Energy Rating System Stand } \\
\text { (2010) }\end{array}$ & & \\
\hline
\end{tabular}

${ }^{6}$ At this writing, only REMrate software is available that can provide both a reference 2009 IECC house design and a performance approach that includes federal minimum equipment efficiencies for a whole-house energy savings analysis. 
Table 7. Comparison of RESNET and BA Energy Usage

\begin{tabular}{|c|c|c|c|c|c|}
\hline \multirow[b]{2}{*}{ Load } & \multicolumn{2}{|c|}{ All Electric } & \multirow[b]{2}{*}{ Load } & \multicolumn{2}{|c|}{ Gas/Electric } \\
\hline & RESNET & $\begin{array}{c}\text { BA } \\
\text { Benchmark }\end{array}$ & & RESNET & $\begin{array}{c}\text { BA } \\
\text { Benchmark }\end{array}$ \\
\hline Lighting & 2,696 & 2,023 & Lighting & 2,696 & 2,023 \\
\hline \multirow[t]{2}{*}{ Refrigerator } & 691 & 434 & Refrigerator & 691 & 434 \\
\hline & & & Range (Gas) & 31 & 29 \\
\hline Range & 448 & 499 & $\begin{array}{c}\text { Range } \\
\text { (Electric) }\end{array}$ & 31 & 80 \\
\hline Dishwasher & 171 & 175 & Dishwasher & 171 & 175 \\
\hline \multirow[t]{2}{*}{$\begin{array}{l}\text { Clothes } \\
\text { Washer }\end{array}$} & 68 & 78 & $\begin{array}{l}\text { Clothes } \\
\text { Washer }\end{array}$ & 68 & 78 \\
\hline & & & Dryer (Gas) & 35 & 39 \\
\hline Clothes Dryer & 971 & 1,076 & $\begin{array}{c}\text { Dryer } \\
\text { (Electric) }\end{array}$ & 76 & 86 \\
\hline \multirow[t]{2}{*}{ Miscellaneous } & 2,805 & 3,591 & Misc. (Electric) & 2,805 & 3,362 \\
\hline & & & Misc. (Gas) & 0 & 8 \\
\hline $\begin{array}{c}\text { Ventilation } \\
\text { Fan }\end{array}$ & 212 & 237 & Ventilation Fan & 212 & 237 \\
\hline \multirow[t]{2}{*}{$\begin{array}{c}\text { Total } \\
\text { Electricity, } \\
\text { Kwh } \\
\end{array}$} & 8,062 & 8,113 & $\begin{array}{c}\text { Total } \\
\text { Electricity, } \\
\text { Kwh } \\
\end{array}$ & 6,750 & 6,474 \\
\hline & & & $\begin{array}{c}\text { Total Gas, } \\
\text { Therms } \\
\end{array}$ & 65 & 76 \\
\hline Total Site Btu & $27,508,347$ & $27,682,255$ & Total Site Btu & $29,571,120$ & $29,650,674$ \\
\hline
\end{tabular}

As shown in the last row of Table 7, there is a minor difference (less than 1\%) between the aggregate energy usage estimates underlying each of the software models; however, there are significant differences within categories (some of which are prescriptive practices in the ICC 700). This reinforces the decision that was made for this analysis to create a reference house in addition to the BEopt baseline benchmark house for the point value analyses that follow. The reference house also contains features consistent with the IECC 2009, such as Section 404.1 requiring $50 \%$ of the hardwired fixtures in the reference house to be high efficacy. Table 8 covers reference house features specified by the 2009 energy code for an energy simulation. 
Table 8. Reference House Features Specified by the 2009 IECC

\begin{tabular}{c|c}
\hline Feature & Quantity \\
\hline Duct Leakage & $6 \%-1 \%^{7}$ \\
\hline Infiltration (Maximum) & SLA $=0.00036^{8}$ \\
\hline Interior Shading - Heat & 0.85 \\
\hline Interior Shading - Cool & 0.70 \\
\hline Lighting, High Efficiency (Minimum) & $50 \%$ \\
\hline Set Point, Heating & $72^{\circ}$ \\
\hline Set Point, Cooling & $75^{\circ}$ \\
\hline Thermostat Heat Set Point & $70^{\circ}$ \\
\hline Thermostat Cool Set Point & $78^{\circ}$ \\
\hline Window Area & $15 \%$ \\
\hline Winter Interior Shade & 0.85 \\
\hline Summer Interior Shade & 0.70 \\
\hline
\end{tabular}

\subsection{Modeling Software and Analysis Methodology}

BEopt version 1.1, developed by National Renewable Energy Laboratory (NREL), ${ }^{9}$ was used to simulate the reference house and each new design that incorporated one practice from section 703. As an initial step in the analysis, the whole-house energy cost (and savings relative to the reference house) for each individual practice in the ICC 700 was calculated. The whole-house approach to savings was used, as it is deemed most representative of assumptions held by consumers and many builders and is in alignment with the BA and ENERGY STAR approaches to reporting the energy efficiency of homes. The approach allows for a simple and as factual as possible comparison between a defined baseline and the anticipated actual usage that may be observed, e.g., by periodic utility bills in an occupied green certified home.

Where software models did not provide options that match directly with the prescriptive provisions but do result in energy savings, the following methodologies were used:

- REScheck software ${ }^{10}$ was used to establish UA percent levels for building envelope features.

- Air and ground source heat pump energy use estimates are based on HVAC performance estimates of energy savings over standard equipment applied to the heating and cooling portion of the whole house estimates.

- Whole-house energy savings estimates for the whole-house fan were based on percent energy savings calculated from REMrate models for that feature.

\footnotetext{
${ }^{7}$ Maximum acceptable leakage threshold varies by level and timing of testing performed. Reference house set up with $6 \%$ leakage.

${ }^{8} 7 \mathrm{ACH} 50$

${ }^{9}$ NREL developed the BEopt software to provide capabilities to evaluate residential building designs and identify cost-optimal efficiency packages at various levels of whole-house energy savings. http://www.nrel.gov/buildings/energy analysis.html

${ }^{10}$ REScheck software, refer to www.energycodes.gov, Build Version 4.4.1.6.
} 
- Energy estimates for the ductless heating and cooling systems were based on total energy savings results from BEopt and apportioned based on the heating and cooling energy estimates for the location.

- Whole-house energy savings estimates for the desuperheater were based on percent energy savings calculated from REMrate ${ }^{11}$ models for that feature.

- Programmable thermostat savings estimated at $1 \%$ of whole-house savings $(2 \%-3 \%$ of heating and cooling energy) due to the inconsistent reports on energy savings. ${ }^{12}$

- Energy use estimates for solar water heaters are based on the methodology outlined in the Solar Rating \& Certification Corporation (SRCC) documentation for calculating savings based on the fuel and tank backup to the solar hot water system for the stated solar energy factor (SEF) and including locality cost of fuel.

Both the original and the proposed versions of the ICC 700 Standard stipulate an energy cost approach for the performance analysis, thus, that is the simulation approach used in this analysis. Utility costs used in each location were developed through an analysis of the Energy Information Administration (EIA) cost data relative to the climate zone(s) of each state. The first step in the analysis was to determine the EIA 2010 state average cost of the utility without service charges. ${ }^{13}$ Next the climate zone or zones for each state were correlated with the EIA cost data. Finally, the average cost was determined for each climate zone, weighting each state and climate zone equally. The result was an average cost for electricity and natural gas for the climate zone. The local average annual costs which were used for the modeling are very close to the national average cost for electricity and natural gas published by EIA. Furthermore, for each climate zone using averaged state utility cost data, the ratio of the electricity cost to the natural gas cost was the same or nearly the same as the ratio of national average cost data. The cost analysis matrix is shown in Appendix A.

The 15 reference houses were simulated as either all electric houses or gas and electric houses, thus, 30 reference house cases were examined in the analysis. Fuel switching was not modeled. In the gas house, all of the equipment that could be fueled with natural gas was modeled with gas. The energy cost difference between the house employing a green practice and the reference house was converted to a percentage (energy) savings for the practice in a matrix.

For the next step, a 40\%-50\% whole house energy savings case was modeled for each reference house based on the available practices in the prescriptive approach (Section 703). Forty percent marks the threshold (Gold) that can be obtained using the prescriptive practices outlined in Section 703, as the 50\% efficiency level of the ICC 700 (Emerald) requires that a performance analysis (Section 702) of the building support the points claimed. Selected $40 \%-50 \%$ cases were also modeled in REM/Rate version 12.96, to provide a test of energy savings attributed to a combination of practices and the results provided through the software. Results from the two

\footnotetext{
${ }^{11} \mathrm{REM} /$ Rate software is used by organizations which operate home energy rating systems (HERS). http://www.archenergy.com/products

${ }^{12}$ Refer to EPA (www.energystar.gov/ia/partners/prod_development/revisions/downloads/thermostats/ Spec_Suspension_Memo_May2009.pdf) and http://money.msn.com/saving-money-tips/post.aspx?post=1453ea21-3702-46319579-858c5e55897c

${ }^{13}$ U.S. Energy Information Administration, www.eia.gov/cneaf/electricity/epa/fig7p5.html http://www.eia.gov/dnav/ng/ng_pri_sum_a_EPG0_PRS_DMcf_m.htm
} 
software programs were similar and the BEopt output was recorded in the matrix for each of the 30 simulations. Again, the maximum cost savings outcomes were interpreted as the percentage of energy savings over the reference house.

The maximum efficiency savings results from the $40 \%-50 \%$ cases compared to the arithmetic sum of individual practices that comprised the cases was however, not equal. This of course is expected, as often system interactions can account for different (and higher) energy use estimates as cumulative efficiency practices are employed, such as the effect of high-efficiency lighting on lower winter heat gain in buildings and higher heat energy demand. The sum of individual savings for each practice was higher than the $40 \%-50 \%$ packages for all of the cases that were analyzed. To compensate for what might otherwise be an overstatement of efficiency gains, a simple ratio between the sum of the individual practices and the combination maximum savings (of the selected efficiency features) was calculated and applied to the efficiency savings estimate for each individual practice in the matrix. This action reduced the individual practice percentage savings estimates by $4 \%-37 \%$, varying by fuel source, location, and foundation type.

Once the efficiency savings of individual practices on the matrices were normalized for the cumulative effect, individual practices within each climate zone's foundation types were averaged, followed by averaging practices by climate zones and then by fuel type. This postprocessing approach refined the simulated results to one matrix consisting of 8 climate zone columns and 83 practices, each with a recommended point assignment. Each cell of the matrix contains a normalized percentage of energy savings that should be representative of the wholehouse efficiency benefit when multiple practices are employed (refer to Appendix B for examples of these matrices).

\subsection{Results: Benchmark Source Energy Savings for the $\mathbf{4 0} \%-\mathbf{5 0} \%$ Case}

Results in the draft normalized energy savings matrix (Appendix B) were also verified by comparing the $40 \%-50 \%$ case to the BA Benchmark. The Benchmark complies with BA simulation protocols (Hendron, R; Engebrecht, C, 2010), whereas the reference and savings cases comply with the 2009 IECC standard reference criteria (Table 405.5.2(1)) (IECC, 2009). Table 9 lists differences in simulation assumptions between the methods.

Table 9. Simulation Protocols

\begin{tabular}{c|c|c}
\hline Feature & Benchmark & Reference and Savings Cases \\
\hline Duct Leakage & $10 \%$ & $6 \%$ \\
\hline Infiltration (Maximum) & $\mathrm{SLA}=0.00036$ & $\mathrm{SLA}=0.00036$ \\
\hline Interior Shading - Heat & 0.70 & 0.85 \\
\hline Interior Shading - Cool & 0.70 & 0.70 \\
\hline Lighting, High Efficiency (Minimum) & $14 \%$ & $50 \%$ \\
\hline Overhang, Zones 1--3 & $2 \mathrm{ft}$ & $2 \mathrm{ft}$ \\
\hline Overhang, Zones 4-8 & $2 \mathrm{ft}$ & $1 \mathrm{ft}$ \\
\hline Set Point, Heating & $71^{\circ}$ & $72^{\circ} \mathrm{F}$ \\
\hline Set Point, Cooling & $76^{\circ} \mathrm{F}$ & $75^{\circ} \mathrm{F}$ \\
\hline Thermostat Heat Set Point & & $70^{\circ} \mathrm{F}$ \\
\hline Thermostat Cool Set Point & & $77^{\circ} \mathrm{F}$ \\
\hline Winter Interior Shade & 0.70 & 0.85 \\
\hline Summer Interior Shade & 0.70 & 0.70 \\
\hline
\end{tabular}


Table 10 and Table 11 indicate the source energy use of the three cases - Benchmark, Reference (2009 IECC), and 40\%-50\% savings case (with the Benchmark serving as baseline). The comparison of the Benchmark to the $40 \%-50 \%$ case and the Benchmark to the reference indicates results are similar to those derived from the straight comparison of the reference to the $40 \%-50 \%$ savings cases that were analyzed for point value recommendations. 
Table 10. Benchmark, Reference, and $\mathbf{4 0} \% \mathbf{- 5 0} \%$ Source Energy Savings Case for Climate Zones 1-3

\begin{tabular}{|c|c|c|c|c|c|c|c|c|c|c|c|c|c|c|c|}
\hline $\begin{array}{c}\text { Location } \\
\text { Climate } \\
\text { Zone } \\
\text { Foundation } \\
\end{array}$ & $\begin{array}{l}\text { Reference } \\
\text { Simulation }\end{array}$ & 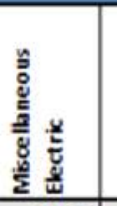 & 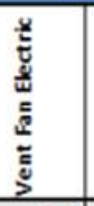 & 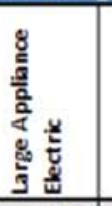 & 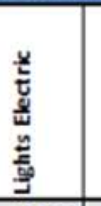 & 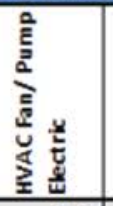 & 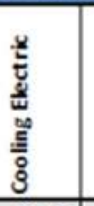 & 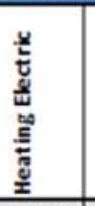 & 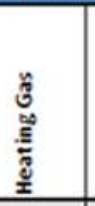 & 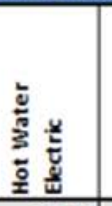 & 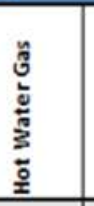 & 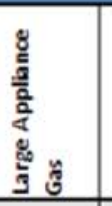 & 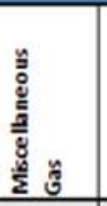 & 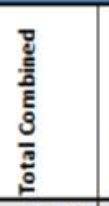 & 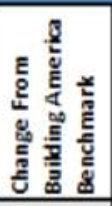 \\
\hline CZ1A & BA Benchmark & 41.23 & 3.19 & 28.68 & 22.77 & 8.28 & 52.06 & 1.13 & & 26.70 & & & & 184.03 & \\
\hline Electric & Reference & 41.23 & 2.49 & 27.04 & 21.72 & 7.66 & 61.09 & 1.72 & & 22.12 & & & & 185.08 & $-0.6 \%$ \\
\hline Slab & $40 \%-50 \%$ Case & 32.16 & 2.49 & 24.46 & 12.92 & 2.73 & 18.04 & 0.60 & & 1.41 & & & & 94.81 & $48.5 \%$ \\
\hline CZ1A & BA Benchmark & 38.60 & 3.19 & 12.49 & 22.77 & 10.76 & 51.59 & & 1.09 & 0.00 & 15.21 & 7.42 & 0.87 & 163.99 & \\
\hline Gas & Reference & 38.60 & 2.49 & 11.89 & 21.72 & 11.83 & 56.43 & & 1.53 & 0.00 & 13.12 & 7.24 & 0.87 & 165.72 & $-1.1 \%$ \\
\hline Slab & $40 \%-50 \%$ Case & 30.10 & 2.49 & 9.31 & 12.92 & 6.21 & 28.76 & & 1.09 & 1.21 & 1.82 & 7.24 & 0.87 & 102.02 & $37.8 \%$ \\
\hline CZ2A & BA Benchmark & 41.23 & 3.19 & 28.68 & 22.77 & 7.22 & 34.10 & 29.82 & & 31.36 & & & & 198.38 & \\
\hline Electric & Reference & 41.23 & 2.49 & 27.04 & 21.72 & 7.28 & 43.54 & 37.53 & & 26.15 & & & & 206.98 & $-4.3 \%$ \\
\hline Slab & $40 \%-50 \%$ Case & 32.16 & 2.49 & 24.46 & 12.92 & 2.43 & 9.94 & 10.53 & & 3.32 & & & & 98.26 & $50.5 \%$ \\
\hline$C Z 2 A$ & BA Benchmark & 38.60 & 3.19 & 12.49 & 22.77 & 5.96 & 34.10 & & 31.12 & 0.00 & 17.15 & 7.42 & 0.87 & 173.68 & \\
\hline Gas & Reference & 38.60 & 2.49 & 11.89 & 21.72 & 7.72 & 42.06 & & 40.95 & 0.00 & 14.73 & 7.24 & 0.87 & 188.27 & $-8.4 \%$ \\
\hline Slab & $40 \%-50 \%$ Case & 30.10 & 2.49 & 9.31 & 12.92 & 2.14 & 17.59 & & 19.11 & 1.14 & 0.77 & 7.24 & 0.87 & 103.68 & $40.3 \%$ \\
\hline CZ 3A & BA Benchmark & 41.23 & 3.19 & 28.68 & 22.77 & 8.06 & 17.87 & 56.53 & & 36.08 & & & & 214.42 & \\
\hline Electric & Reference & 41.23 & 2.49 & 27.04 & 21.72 & 8.99 & 24.68 & 67.54 & & 30.22 & & & & 223.92 & $-4.4 \%$ \\
\hline Crawl & $40 \%-50 \%$ Case & 32.16 & 2.49 & 24.46 & 12.92 & 2.97 & 6.29 & 22.58 & & 4.14 & & & & 108.01 & $49.6 \%$ \\
\hline CZ 3A & BA Benchmark & 41.23 & 3.19 & 28.68 & 22.77 & 9.02 & 18.29 & 69.60 & & 36.08 & & & & 228.87 & \\
\hline Electric & Reference & 41.23 & 2.49 & 27.04 & 21.72 & 8.32 & 23.78 & 76.95 & & 30.22 & & & & 231.75 & $-1.3 \%$ \\
\hline Slab & $40 \%-50 \%$ Case & 41.23 & 2.49 & 24.46 & 12.92 & 3.07 & 6.09 & 23.21 & & 4.14 & & & & 117.61 & $48.6 \%$ \\
\hline$C Z 3 A$ & BA Benchmark & 38.60 & 3.19 & 12.49 & 22.77 & 5.59 & 18.20 & & 69.12 & 0.00 & 19.11 & 7.42 & 0.87 & 197.37 & \\
\hline Gas & Reference & 38.60 & 2.49 & 11.89 & 21.72 & 6.96 & 22.95 & & 79.61 & 0.00 & 16.37 & 7.24 & 0.87 & 208.70 & $-5.7 \%$ \\
\hline Slab & $40 \%-50 \%$ Case & 30.10 & 2.49 & 9.31 & 12.92 & 2.01 & 7.45 & & 30.25 & 1.16 & 1.01 & 7.24 & 0.87 & 104.82 & $46.9 \%$ \\
\hline $\mathrm{CZ} 3 \mathrm{~B}$ & BA Benchmark & 41.23 & 3.19 & 28.68 & 22.77 & 10.41 & 45.33 & 43.09 & & 32.09 & & & & 226.80 & \\
\hline Electric & Reference & 41.23 & 2.49 & 27.04 & 21.72 & 9.69 & 54.19 & 48.77 & & 26.76 & & & & 231.90 & $-2.2 \%$ \\
\hline Slab & $40 \%-50 \%$ Case & 32.16 & 2.49 & 24.46 & 12.92 & 3.55 & 19.61 & 18.21 & & 1.95 & & & & 115.35 & $49.1 \%$ \\
\hline $\mathrm{CZ} 3 \mathrm{~B}$ & BA Benchmark & 38.60 & 3.19 & 12.49 & 22.77 & 8.35 & 43.74 & & 47.07 & 0.00 & 17.45 & 7.42 & 0.87 & 201.95 & \\
\hline Gas & Reference & 38.60 & 2.49 & 11.89 & 21.72 & 10.08 & 50.85 & & 54.93 & 0.00 & 14.98 & 7.24 & 0.87 & 213.66 & $-5.8 \%$ \\
\hline Slab & $40 \%-50 \%$ Case & 30.10 & 2.49 & 9.31 & 12.92 & 2.64 & 22.19 & & 19.44 & 1.26 & 0.23 & 7.24 & 0.87 & 108.69 & $46.2 \%$ \\
\hline
\end{tabular}


Table 11. Benchmark, Reference, and 40\%-50\% Source Energy Savings Case for Climate Zones 4-8

\begin{tabular}{|c|c|c|c|c|c|c|c|c|c|c|c|c|c|c|c|}
\hline $\begin{array}{l}\text { Location } \\
\text { Climate } \\
\text { Zone } \\
\text { Foundation }\end{array}$ & $\begin{array}{l}\text { Reference } \\
\text { Simulation }\end{array}$ & 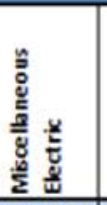 & 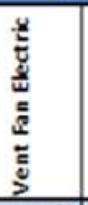 & 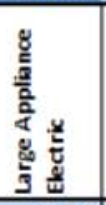 & 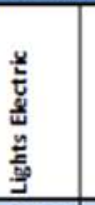 & 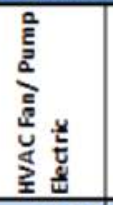 & 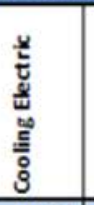 & 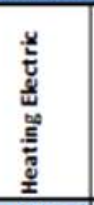 & 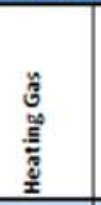 & 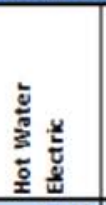 & 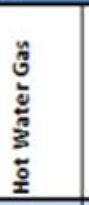 & 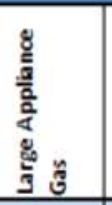 & 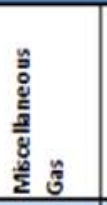 & 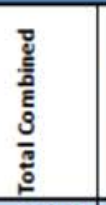 & 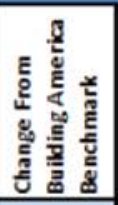 \\
\hline$C Z 4 A$ & BA Benchmark & 41.23 & 3.19 & 28.68 & 22.77 & 11.84 & 11.53 & 100.60 & & 40.47 & & & & 260.31 & \\
\hline Electric & Reference & 41.23 & 2.49 & 27.04 & 21.72 & 11.10 & 14.85 & 98.71 & & 34.01 & & & & 251.14 & $3.5 \%$ \\
\hline Basement & $40 \%-50 \%$ Case & 41.23 & 2.49 & 24.46 & 12.92 & 3.58 & 4.45 & 37.15 & & 11.10 & & & & 137.39 & $47.2 \%$ \\
\hline CZ 4A & BA Benchmark & 38.60 & 3.19 & 12.49 & 22.77 & 5.52 & 12.00 & & 99.70 & 0.00 & 20.94 & 7.42 & 0.87 & 223.50 & \\
\hline Gas & Reference & 38.60 & 2.49 & 11.89 & 21.72 & 7.60 & 14.82 & & 96.97 & 0.00 & 17.89 & 7.24 & 0.87 & 220.10 & $1.5 \%$ \\
\hline Basement & $40 \%-50 \%$ Case & 30.10 & 2.49 & 9.31 & 12.92 & 2.73 & 5.69 & & 49.03 & 1.26 & 3.64 & 7.24 & 0.87 & 125.29 & $43.9 \%$ \\
\hline $\mathrm{CZ} 4 \mathrm{C}$ & BA Benchmark & 41.23 & 3.19 & 28.68 & 22.77 & 7.28 & 1.61 & 75.10 & & 42.91 & & & & 222.77 & \\
\hline Electric & Reference & 41.23 & 2.49 & 27.04 & 21.72 & 7.80 & 2.49 & 80.31 & & 36.13 & & & & 219.21 & $1.6 \%$ \\
\hline Crawl & $40 \%-50 \%$ Case & 32.16 & 2.49 & 24.46 & 12.92 & 2.23 & 0.87 & 21.75 & & 33.59 & & & & 130.46 & $41.4 \%$ \\
\hline CZ 4C & BA Benchmark & 38.60 & 3.19 & 12.49 & 22.77 & 3.20 & 0.72 & & 86.05 & & 21.95 & 7.42 & 0.87 & 197.26 & \\
\hline Gas & Reference & 38.60 & 2.49 & 11.89 & 21.72 & 4.27 & 1.76 & & 83.76 & & 18.74 & 7.24 & 0.87 & 191.34 & $3.0 \%$ \\
\hline Crawl & $40 \%-50 \%$ Case & 30.10 & 2.49 & 9.31 & 12.92 & 1.71 & 0.53 & & 37.56 & & 12.59 & 7.24 & 0.87 & 115.33 & $41.5 \%$ \\
\hline CZ5A & BA Benchmark & 41.23 & 3.19 & 28.68 & 22.77 & 14.19 & 6.19 & 142.23 & & 44.57 & & & & 303.05 & \\
\hline Electric & Reference & 41.23 & 2.49 & 27.04 & 21.72 & 12.73 & 9.25 & 139.01 & & 37.55 & & & & 291.02 & $4.0 \%$ \\
\hline Basement & $40 \%-50 \%$ Case & 32.16 & 2.49 & 24.46 & 12.92 & 4.07 & 2.53 & 50.20 & & 15.09 & & & & 143.91 & $52.5 \%$ \\
\hline CZ 5A & BA Benchmark & 38.60 & 3.19 & 12.49 & 22.77 & 5.72 & 5.98 & & 127.11 & 0.00 & 22.64 & 7.42 & 0.87 & 246.79 & \\
\hline Gas & Reference & 38.60 & 2.49 & 11.89 & 21.72 & 7.77 & 8.58 & & 123.07 & 0.00 & 19.31 & 7.24 & 0.87 & 241.55 & $2.1 \%$ \\
\hline Basement & $40 \%-50 \%$ Case & 38.60 & 2.49 & 9.31 & 12.92 & 2.65 & 3.81 & & 51.98 & 1.23 & 5.26 & 7.24 & 0.87 & 136.36 & $44.7 \%$ \\
\hline$C Z 6 A$ & BA Benchmark & 38.60 & 3.19 & 12.49 & 22.77 & 6.62 & 5.02 & & 148.95 & & 23.83 & 7.42 & 0.87 & 269.76 & \\
\hline Gas & Reference & 38.60 & 2.49 & 11.89 & 21.72 & 8.73 & 7.38 & & 146.11 & & 20.73 & 7.24 & 0.87 & 265.76 & $1.5 \%$ \\
\hline Basement & $40 \%-50 \%$ Case & 30.10 & 2.49 & 10.50 & 12.92 & 5.28 & 3.63 & & 63.99 & & 13.32 & 7.24 & 0.87 & 150.34 & $44.3 \%$ \\
\hline $\mathrm{CZ} 6 \mathrm{~B}$ & BA Benchmark & 38.60 & 3.19 & 12.49 & 22.77 & 5.56 & 1.71 & & 134.86 & & 24.12 & 7.42 & 0.87 & 251.59 & \\
\hline Gas & Reference & 38.60 & 2.49 & 11.64 & 21.72 & 7.30 & 3.32 & & 129.73 & & 22.71 & 7.86 & 0.87 & 246.25 & $2.1 \%$ \\
\hline Basement & $40 \%-50 \%$ Case & 30.10 & 2.49 & 9.31 & 12.92 & 4.45 & 1.31 & & 59.08 & & 14.40 & 7.24 & 0.87 & 142.18 & $43.5 \%$ \\
\hline CZ7 & BA Benchmark & 38.60 & 3.19 & 12.49 & 22.77 & 7.76 & 0.64 & & 189.90 & & 25.78 & 7.42 & 0.87 & 309.42 & \\
\hline Gas & Reference & 38.60 & 2.49 & 11.89 & 21.72 & 9.61 & 1.62 & & 181.49 & & 21.93 & 7.24 & 0.87 & 297.46 & $3.9 \%$ \\
\hline Basement & $40 \%-50 \%$ Case & 30.10 & 2.49 & 9.31 & 12.92 & 5.74 & 0.47 & & 78.84 & & 15.78 & 7.24 & 0.87 & 163.77 & $47.1 \%$ \\
\hline CZ8 & BA Benchmark & 38.60 & 3.19 & 12.49 & 22.77 & 13.90 & 0.02 & & 304.12 & & 28.65 & 7.42 & 0.87 & 432.04 & \\
\hline Gas & Reference & 38.60 & 2.49 & 11.89 & 21.72 & 13.61 & 0.55 & & 287.20 & & 24.33 & 7.24 & 0.87 & 408.49 & $5.5 \%$ \\
\hline Slab & $40 \%-50 \%$ Case & 30.10 & 2.49 & 9.31 & 12.92 & 7.67 & 0.15 & & 105.27 & & 18.17 & 7.24 & 0.87 & 194.20 & $55.1 \%$ \\
\hline
\end{tabular}


The highlighted boxes in Table 12 describe the principal practices that comprise the $40 \%-50 \%$ EE cases that were analyzed. Under the proposed draft point scheme of one point being equal to $1 / 2 \%$ energy savings, the range of savings suggested is $41 \%-51 \%$, dependent on climate zone.

Table 12. Initial $\mathbf{4 0} \% \mathbf{- 5 0 \%}$ Case Practices Analysis

\begin{tabular}{|c|c|c|c|c|c|c|c|c|c|}
\hline \multirow{2}{*}{$\begin{array}{l}\text { Chapter } \\
\text { Section }\end{array}$} & \multirow[t]{2}{*}{ Practice } & \multicolumn{8}{|c|}{$\begin{array}{c}\text { Proposed Point Table } \\
\text { by Climate Zone }\end{array}$} \\
\hline & & 1 & 2 & 3 & 4 & 5 & 6 & 7 & 8 \\
\hline & $15 \%$ to $<20 \%$ UA Improvement & 0 & 13 & 14 & 14 & 15 & 14 & 13 & 13 \\
\hline & $\geq 20 \%$ UA Improvement & 1 & 14 & 17 & 19 & 18 & 17 & 16 & 16 \\
\hline \multirow[t]{3}{*}{703.1 .2} & Insulation Installation Quality & 2 & 2 & 2 & 2 & 2 & 2 & 2 & 2 \\
\hline & $2 \mathrm{ACH} 50$ & 3 & 5 & 8 & 11 & 15 & 18 & 23 & 24 \\
\hline & $1 \mathrm{ACH} 50$ & 4 & 3 & 9 & 13 & 17 & 19 & 26 & 25 \\
\hline \multirow[t]{3}{*}{ 703.1.6.2b } & Fenestration Level 3 & 10 & 8 & 8 & 4 & 8 & 9 & 10 & 7 \\
\hline & Fenestration Level 4 & & & & 6 & 9 & 9 & 10 & 7 \\
\hline & Gas Heater $>98 \%$ & 1 & 6 & 12 & 13 & 15 & 15 & 18 & 18 \\
\hline \multirow[t]{3}{*}{$703.2 .5(1)$} & SEER 14 & 4 & 3 & 1 & 1 & 0 & 0 & 0 & 0 \\
\hline & SEER 19 & 17 & 12 & 6 & 3 & 2 & 1 & 0 & 0 \\
\hline & $\begin{array}{c}\text { Any Type } 24 \text { EER } 4.3 \text { Coefficient of } \\
\text { Performance }\end{array}$ & 29 & 30 & 29 & 37 & 42 & 47 & 57 & 57 \\
\hline 703.2.10 & Programmable Thermostat 70/75 & 1 & 1 & 1 & 2 & 2 & 2 & 2 & 2 \\
\hline \multirow[t]{2}{*}{703.3 .3} & Duct Installation (Interior+) & 17 & 11 & 11 & 8 & 4 & 3 & 3 & 23 \\
\hline & $6 \%$ in & 4 & 3 & 1 & 1 & 1 & 0 & 0 & 3 \\
\hline \multirow[t]{4}{*}{ 703.4.1 (1) } & Water Heater Energy Factor $\geq 0.80$ & 7 & 5 & 6 & 4 & 5 & 4 & 3 & 2 \\
\hline & SEF 2.31 & 24 & 20 & 20 & 14 & 23 & 16 & 13 & 7 \\
\hline & SEF 3.01 & 27 & 22 & 22 & 16 & 26 & 18 & 15 & 8 \\
\hline & Hardwired Lighting 95\% HE & 7 & 6 & 4 & 5 & 5 & 4 & 3 & 3 \\
\hline \multirow[t]{2}{*}{703.6 .1} & Passive Solar Design & 10 & 10 & 10 & 2 & 7 & 7 & 7 & 2 \\
\hline & Total Points $(1$ point $=1 / 2 \%$ EE $)$ & 102 & 102 & 101 & 102 & 100 & 82 & 91 & 102 \\
\hline
\end{tabular}

\subsection{Energy Efficiency Point Value Recommendations}

The final step in the analysis was conversion of the normalized savings estimates to the point scale used by ICC 700-2008 (ANSI/NAHB ICC 700-2008, 2009), which was one point for each half percent of energy savings. The normalized savings estimates were simply doubled and rounded to the nearest whole digit to convert the percentage of energy savings to suggested point values for the revised ICC 700. It is reasonable to keep the weight of the points similar from each version of the Standard to the next, thus, this analysis suggests the simplicity of the approach and presents a similar point scale for consideration based on the houses and practices described herein. In addition, where modeling was not feasible for some practices (e.g., insulation installation quality,) the extant point scale has been forwarded in this document. Table 13 and Table 14 present the draft point scale suggested by the process outlined herein. The columns on the left represent the simulated, normalized points recommended by this analysis and the 
columns on the right allow comparison of points for the practice to the original ANSI/NAHB ICC 700-2008. Further modifications to the table will be made through the ANSI Standard revision process. 


\section{Table 13. Initial Matrix of Proposed Points With Comparison to ANSI/NAHB ICC 700-2008 Points, 1 of 2}

\begin{tabular}{|c|c|c|c|c|c|c|c|c|c|c|c|c|c|c|c|c|c|}
\hline \multirow{2}{*}{$\begin{array}{l}\text { Chapter } \\
\text { Section }\end{array}$} & \multirow{2}{*}{ Practice } & \multicolumn{8}{|c|}{ Proposed Point Table } & \multicolumn{8}{|c|}{ ICC-700-2008 Point Table } \\
\hline & & $c_{2}$ & $\mathrm{C2} 2$ & $\mathrm{C}_{3} 3$ & Cz4 & C25 & Q 6 & C27 & $\mathrm{Cz} 8$ & $C_{2} 2$ & $\mathrm{CZ}_{2}$ & $c_{3}$ & $a_{4}$ & C2s & 26 & Q7 7 & $\mathrm{C} 8$ \\
\hline \multirow[t]{5}{*}{203.1 .1} & 0 to 5 S\% UA improvement & 0 & 1 & 0 & 0 & 0 & 0 & 0 & 0 & 0 & 0 & 0 & 0 & \multicolumn{2}{|c|}{0} & \multicolumn{2}{|c|}{0} \\
\hline & $5 \%$ to $<10 \%$ UA improvement & 0 & 2 & -1 & 4 & 7 & 3 & 3 & 4 & 0 & 5 & 6 & 7 & \multicolumn{2}{|c|}{8} & \multicolumn{2}{|c|}{9} \\
\hline & $10 \%$ to $<155$ UA improvement & 0 & 6 & 5 & 8 & 11 & 12 & 9 & 10 & 0 & 10 & 12 & 14 & \multicolumn{2}{|c|}{16} & \multicolumn{2}{|c|}{18} \\
\hline & $15 \%$ to $<20 \%$ UA improvement & 0 & 10 & 10 & 13 & 16 & 14 & 11 & 12 & 0 & 15 & 18 & 21 & \multicolumn{2}{|c|}{24} & \multicolumn{2}{|c|}{27} \\
\hline & $3 \approx 20 \%$ UA improvement & 2 & 14 & 17 & 18 & 18 & 17 & 14 & 16 & 0 & 20 & 24 & 28 & \multicolumn{2}{|c|}{32} & \multicolumn{2}{|c|}{36} \\
\hline 03.1 .2 & insulation installation quality & 2 & 2 & 2 & 2 & 2 & 2 & 2 & 2 & \multicolumn{8}{|c|}{ 15. Grade 1,10 Grade 2} \\
\hline \multirow{2}{*}{203.1 .3} & Mass walls $>6^{-1}$ & 5 & 5 & 5 & 5 & 4 & 3 & 0 & 0 & \multicolumn{4}{|c|}{6} & \multicolumn{2}{|c|}{5} & \multicolumn{2}{|c|}{0} \\
\hline & mass walls $\leq 6^{\prime \prime 2}$ & 3 & 3 & 3 & 3 & 2 & 2 & 0 & 0 & \multicolumn{4}{|c|}{4} & & & & 0 \\
\hline 03.1 .4 & Radiant barrier & 2 & 3 & 1 & 1 & 0 & 0 & 0 & 1 & & 2 & & 1 & & & & \\
\hline 03.1 .5 & Envelope leakage 5ACH50 & 2 & 3 & 3 & 4 & 6 & 7 & 8 & 9 & & & & & & & & \\
\hline & $4 A C H 5 O$ & 3 & 4 & 5 & 7 & 10 & 12 & 13 & 14 & & & & & & & & \\
\hline & $3 A C H S O$ & 3 & 5 & 6 & 9 & 13 & 15 & 17 & 19 & & & & & & & & \\
\hline & $2 \mathrm{ACHSO}$ & 4 & 6 & 8 & 11 & 15 & 18 & 20 & 23 & & & & & & & & \\
\hline & IACH5O & 4 & 5 & 8 & 12 & 17 & 19 & 22 & 24 & & & & & & & & \\
\hline p03.1.6.1 & Fenestration level 1 & & $\mathrm{iCC}-7$ & Base (h) & er pert: & ancele & than if & 2009) & & & & & Not: & vered & & & \\
\hline 703.1 .6 .2 & Fenestration level 2 & 10 & 5 & 6 & 2 & 5 & $s$ & 5 & 4 & & 8 & & & & & 6 & \\
\hline 03.1 .6 .26 & Fenestration level 3 & 13 & 9 & 9 & 4 & 8 & 9 & 9 & 6 & & 10 & & & & & 12 & \\
\hline & Fenestration level 4 & & & & 5 & 9 & 9 & 9 & 7 & & & & Not: & vered & & & \\
\hline 703.2 .1 & Combo heating system & 4 & 4 & 4 & 4 & 4 & 4 & 4 & 4 & & & & & & & & \\
\hline 203.2.2(1) & Gas Heater $>90 \%$ & 0 & 5 & 6 & 7 & 9 & 9 & 7 & 10 & 0 & 2 & 5 & 8 & 11 & & 14 & \\
\hline & Gas Heater $>922 \mathrm{~K}$ & 0 & 5 & 8 & 9 & 11 & 11 & 9 & 12 & 0 & 2 & 6 & 9 & 12 & & 15 & \\
\hline & Gas Heater $>94 \mathrm{~K}$ & 0 & 5 & 8 & 10 & 13 & 13 & 10 & 14 & 0 & 3 & 7 & 10 & 14 & & 17 & \\
\hline & Gas Heater $296 \mathrm{~K}$ & 1 & 6 & 10 & 11 & 14 & 14 & 12 & 16 & & & & Not $C$ & vered & & & \\
\hline & Gas Heater $>98 \%$ & 1 & 6 & 10 & 13 & 16 & 15 & 13 & 17 & & & & Not & vered & & & \\
\hline $003.2 .2(2)$ & Oil Furnace $85 \%$ & 0 & 1 & 3 & 3 & 7 & 7 & 7 & 7 & 0 & 1 & 3 & 3 & 7 & & 7 & \\
\hline & Oil Furnace $90 \%$ & 0 & 2 & 5 & 8 & 11 & 14 & 14 & 14 & 0 & 2 & 5 & 8 & 11 & & 14 & \\
\hline $003.2 .2(3)$ & Gas Boiler >BS\% & 0 & 9 & 16 & 18 & 17 & 16 & 13 & 26 & 0 & 1 & 3 & 4 & 6 & & 7 & \\
\hline & Gas Boiler $290 \%$ & 1 & 10 & 17 & 19 & 18 & 17 & 13 & 28 & 0 & 2 & 5 & 8 & 11 & & 14 & \\
\hline & Gas Boiler $>94 \%$ & 1 & 10 & 18 & 19 & 19 & 17 & 14 & 29 & 0 & 3 & 7 & 10 & 14 & & 17 & \\
\hline & Gas Boiler $>96 \%$ & 1 & 10 & 18 & 20 & 19 & 18 & 14 & 30 & & & & & & & & \\
\hline $003.2 .2(4)$ & oil Boil 85\% & 0 & 9 & 16 & 18 & 17 & 16 & 13 & 26 & 0 & 1 & 3 & 4 & 6 & & 7 & \\
\hline & Oil soiler $90 \%$ & 1 & 10 & 17 & 19 & 18 & 17 & 13 & 28 & 0 & 2 & 5 & 8 & 11 & & 14 & \\
\hline 203.2 .3 & Boller temperature reset & 1 & 1 & 1 & 1 & 1 & 1 & 1 & 1 & & & & & & & & \\
\hline 03.2 .4 & $8.2 \mathrm{HSPF}$ & 0 & 1 & 2 & 4 & 5 & 6 & 7 & 7 & 0 & 1 & 2 & 5 & 7 & & 7 & \\
\hline & 9.0 HSPF & 0 & 3 & 6 & 9 & 12 & 14 & 17 & 17 & 0 & 2 & 5 & 10 & 11 & & 12 & \\
\hline & $9.5 \mathrm{HSPF}$ & 0 & 4 & 7 & 12 & 16 & 18 & 23 & 23 & & & & Not: & vered & & & \\
\hline & $10.0 \mathrm{HSPF}$ & 1 & 4 & 9 & 15 & 19 & 22 & 28 & 27 & & & & Nots & vered & & & \\
\hline
\end{tabular}




\section{Table 14. Initial Matrix of Proposed Points With Comparison to ANSI/NAHB ICC 700-2008 Points, 2 of 2}

\begin{tabular}{|c|c|c|c|c|c|c|c|c|c|c|c|c|c|c|c|c|c|}
\hline \multirow{2}{*}{$\begin{array}{l}\text { Chapter } \\
\text { Section }\end{array}$} & \multirow{2}{*}{ Practice } & \multicolumn{8}{|c|}{ Proposed Point Table } & \multicolumn{8}{|c|}{ ICC-700-2008 Point Table } \\
\hline & & $\mathrm{CZ}_{1}$ & $\mathrm{CZ2}_{2}$ & $\mathrm{CZ}_{3}$ & $\mathrm{CZ} 4$ & C25 & $\mathrm{CZ} 6$ & $\mathrm{CZ7}$ & $\mathrm{CZ} 8$ & $\mathrm{CZ}_{1}$ & $\mathrm{CZ}_{2}$ & $\mathrm{CZ}_{3}$ & $c_{4}$ & CZ5 & CZ6 & $C_{7}$ & $C 8$ \\
\hline \multirow{5}{*}{$703.2 .5(1)$} & SEER 14 & 4 & 3 & 1 & 1 & 0 & 0 & 0 & 0 & 8 & 6 & 2 & 2 & 1 & & 1 & \\
\hline & SEER 15 & 7 & 5 & 2 & 1 & 1 & 0 & 0 & 0 & 12 & 10 & 4 & 3 & 2 & & 2 & \\
\hline & SEER 17 & 12 & 8 & 4 & 2 & 1 & 1 & 0 & 0 & 18 & 14 & 6 & 4 & 3 & & 3 & \\
\hline & SEER 19 & 16 & 11 & 6 & 3 & 2 & 1 & 0 & 0 & 24 & 18 & 8 & 4 & 3 & & 3 & \\
\hline & SEER 21 & 19 & 14 & 7 & 3 & 2 & 1 & 0 & 0 & \multicolumn{8}{|c|}{ Not Covered } \\
\hline $703.2 .5(2)$ & WaterSource 15.OEER 4.O COP & 14 & 18 & 22 & 30 & 37 & 43 & 53 & 52 & 18 & 14 & 6 & 4 & 3 & & 3 & \\
\hline \multirow[t]{5}{*}{703.2 .6} & GSHP 16.2EER $3.6 \mathrm{co \rho}$ & 17 & 18 & 20 & 27 & 33 & 37 & 45 & 45 & \multicolumn{8}{|c|}{20} \\
\hline & GSHP 14.1EER 3.3 COP & 12 & 14 & 16 & 22 & 27 & 31 & 38 & 38 & \multicolumn{8}{|c|}{20} \\
\hline & GSHP 15 EER 3.5 cop & 14 & 16 & 19 & 25 & 31 & 35 & 43 & 42 & \multicolumn{8}{|c|}{20} \\
\hline & Any type 24 EER 4.3 cop & 29 & 28 & 29 & 35 & 42 & 47 & 57 & 57 & \multirow{2}{*}{\multicolumn{8}{|c|}{$\begin{array}{c}30 \\
\text { Not Covered }\end{array}$}} \\
\hline & Any type 28 EER 4.8 cop & 32 & 32 & 32 & 40 & 47 & 53 & 64 & 63 & & & & & & & & \\
\hline 703.2 .7 & E" ceeiling fans & 1 & 1 & 1 & 1 & 1 & 1 & 1 & 1 & \multicolumn{8}{|c|}{$\begin{array}{c}\text { Not Covered } \\
1\end{array}$} \\
\hline 703.2 .8 & whole house ventilation fan & 5 & 0 & 2 & 3 & 5 & 3 & 2 & 2 & \multicolumn{8}{|c|}{2} \\
\hline 703.2 .9 & submeter in multiunit & 1 & 1 & 1 & 1 & 1 & 1 & 1 & 1 & \multirow{2}{*}{\multicolumn{8}{|c|}{1}} \\
\hline 703.2 .10 & Programmable thermostat $70 / 78$ & 2 & 1 & 1 & 1 & 2 & 2 & 1 & 1 & & & & & & & & \\
\hline 703.3 .1 & Ductless heating system & 20 & 4 & 7 & 7 & $\frac{2}{6}$ & 3 & 3 & 23 & \multicolumn{8}{|c|}{15} \\
\hline 703.3 .2 & Ductless cooling system & 10 & 7 & 3 & 1 & 0 & 0 & 0 & 0 & \multicolumn{8}{|c|}{15} \\
\hline 703.3 .3 & Duct installation (interiort) & 11 & 11 & 11 & 8 & 4 & 3 & 15 & 28 & & & & & & & & \\
\hline 703.3 .4 & Duct leakage $6 \%$ & 5 & 8 & 4 & 2 & 2 & 1 & 1 & 8 & & & & & & & & \\
\hline & $6 \%$ in & 2 & 3 & 1 & 1 & 1 & 0 & 0 & 3 & & & & & & & & \\
\hline & $6 \%$ both & 5 & 8 & 4 & 2 & 2 & 1 & 1 & 8 & & & & & & & & \\
\hline $703.4 .1(1)$ & Water heater energy factor $z .80$ & 7 & 7 & 5 & 4 & 5 & 4 & 2 & 2 & & & & & & & & \\
\hline $703.4 .1(2)$ & Water heater energy factor .95 & 2 & 1 & 2 & 1 & 1 & 1 & 1 & 1 & & & & & & & & \\
\hline $703.4 .1(3)$ & Oil Water Heating & 1 & 1 & 1 & 1 & 1 & 1 & 1 & 1 & & & & & & & & \\
\hline 703.4.1(4) & Heat Pump Water Heater EF 1.5 & 14 & 11 & 11 & 11 & 11 & 11 & 9 & 4 & & & & & & & & \\
\hline & Heat Pump Water Heater EF 2.0 & 19 & 15 & 16 & 15 & 15 & 15 & 12 & 6 & & & & & & & & \\
\hline & Heat Pump Water Heater EF 2.2 & 20 & 16 & 17 & 17 & 16 & 16 & 13 & 6 & & & & Not & yered & & & \\
\hline 703.4 .2 & Desuperheater & 17 & 11 & 8 & 8 & 8 & 7 & 5 & 4 & & & & & & & & \\
\hline 703.4 .3 & Drainwater heat recovery & 2 & 2 & 2 & 2 & 2 & 2 & 2 & 2 & & & & & & & & \\
\hline 703.4 .4 & Indirect water heater & 1 & 1 & 1 & 1 & 1 & 1 & 1 & 1 & & & & & & & & \\
\hline 703.4 .5 & Solar water heater SEF 1.3 & 15 & 10 & 11 & 10 & 12 & 10 & 7 & 4 & & & & & & & & \\
\hline & SEF 1.51 & 18 & 12 & 14 & 12 & 15 & 12 & 8 & 5 & & & & & & & & \\
\hline & SEF 1.81 & 21 & 14 & 16 & 14 & 18 & 14 & 10 & 6 & & & & & & & & \\
\hline & SEF 2.31 & 24 & 17 & 19 & 17 & 22 & 16 & 12 & 7 & & & & & & & & \\
\hline & SEF 3.01 & 27 & 19 & 21 & 19 & 25 & 18 & 13 & 8 & & & & & & & & \\
\hline 703.5 .1 & Hardwired lighting $75 \%$ HE & 5 & 4 & 3 & 3 & 3 & 2 & 2 & 1 & & & & Not & vered & & & \\
\hline & Hardwired lighting 95\% HE & 9 & 6 & 5 & 4 & 4 & 3 & 2 & 1 & & & & Not & vered & & & \\
\hline 703.5 .2 & \begin{tabular}{|l} 
Recessed lighting \\
\end{tabular} & $\frac{3}{2}$ & 2 & $\frac{3}{2}$ & 2 & 2 & $\frac{3}{2}$ & 2 & $\frac{2}{2}$ & & & & & & & & \\
\hline 703.5 .3 & $\mathrm{E}^{*}$ Refrigerator & 3 & 3 & 2 & 1 & 1 & 2 & 1 & 0 & & & & & & & & \\
\hline & $E^{*}$ DW & 1 & 1 & 1 & 1 & 1 & 1 & 1 & 1 & & & & & & & & \\
\hline & $E^{*}$ Washing Machine & 4 & 4 & 4 & 4 & 4 & 4 & 4 & 4 & & & & & & & & \\
\hline 703.5 .4 & Induction cooktop & 1 & 1 & 1 & 1 & 1 & 1 & 1 & 1 & & & & & & & & \\
\hline 703.6 .1 & Passive solar design & 5 & 5 & 5 & 5 & 5 & 5 & 5 & 5 & & & & & & & & \\
\hline 703.6 .2 & Window shading (active) h/c & 1 & 1 & 1 & 1 & 1 & 1 & 1 & 1 & & & & & & & & \\
\hline 703.6 .3 & Passive cooling design & $3+1$ & $3+1$ & $3+1$ & $3+1$ & $3+1$ & $3+1$ & $3+1$ & $3+1$ & & & & & & & & \\
\hline 703.6 .4 & Passive heating (mass) & 4 & 4 & 4 & 4 & 4 & 4 & 4 & 4 & & & & & & & & \\
\hline
\end{tabular}




\section{Summary}

The proposed point structure for the prescriptive approach of the Energy Efficiency chapter of the NGBS was developed with support from BA house design and simulation protocols. The source energy was calculated for both the reference home and the proposed house in each specific climate. This analysis also compared the simulated energy performance of a home designed to meet the revised NGBS Chapter 7 at the Gold level with reference to the 2010 BA Benchmark using the BA House Simulation Protocols. The results of modeling various houses in multiple climate zones indicate that the range of energy savings for the designs is $40 \%-50 \%$ for the Gold level. This range aligns well with BA program energy savings goals of $30 \%-50 \%$ whole-house energy savings.

Additional BA quality criteria, such as water management and indoor environmental quality, are promoted in Chapters 8 and 9 of the NGBS as both mandatory and point-based provisions. This aligns with the goals of BA and Builders Challenge to build homes that are energy efficient, safe, comfortable, and durable. 


\section{References}

Hendron, R; Engebrecht, C. (2010). Building America House Simulation Protocols. U.S. Department of Energy Building Technologies Program. Golden, CO: National Renewable Energy Laboratory. http://apps1.eere.energy.gov/buildings/publications/pdfs/

building_america/house_simulation_revised.pdf.

ICC 700-2008. (2009). National Green Building Standard. National Association of Home Builders (NAHB). Washington, D.C.

IECC. (2009). International Energy Conservation Code, International Code Council (ICC), Country Club Hills, IL.

IECC. (2012). International Energy Conservation Code, International Code Council (ICC), Country Club Hills, IL.

NAHB Research Center. (2009). Contribution to Best Practice Case Studies (Green Building Standard/BA Joule Target Analysis: for New Home Construction, NREL Subcontract Number AXL-9-99208-01.

NAHB Research Center. (2009). Contribution to BA Best Practices Alignment of Builders Challenge with the National Green Building Standard, NREL Subcontract Number ADJ-666256-01. 


\section{Appendix A Cost Matrix: Electric and Gas}

Table 15. Electric Rate Cost Matrix

\begin{tabular}{|c|c|c|c|c|c|c|c|c|c|c|}
\hline \multirow{2}{*}{\multicolumn{3}{|c|}{ Average Across States -> }} & \multicolumn{8}{|c|}{ Electric Rate State Average, cents/kWh } \\
\hline & & & 24.2 & \multirow[t]{2}{*}{\begin{tabular}{l|l}
10.9 & \\
\end{tabular}} & \multirow[t]{2}{*}{10.6} & \multirow[t]{2}{*}{11.1} & \multirow[t]{2}{*}{\begin{tabular}{l|l}
11.7 & \\
\end{tabular}} & \multirow[t]{2}{*}{11.5} & \multirow[t]{2}{*}{11.7} & 17.1 \\
\hline \multicolumn{3}{|c|}{ State Utility Rate } & \multirow[b]{2}{*}{ CZ1 } & & & & & & & \\
\hline State & $\begin{array}{c}\text { Electric } \\
\text { cents } / \mathrm{kWh}\end{array}$ & $\begin{array}{c}\text { Gas } \\
\$ \text { /therm }\end{array}$ & & CZ2 & $\mathbf{C Z 3}$ & CZ4 & CZ5 & CZ6 & CZ7 & CZ8 \\
\hline Alabama & 10.66 & 1.04 & & & 10.7 & & & & & \\
\hline Alaska & 17.14 & 1.67 & & & & & & & 17.1 & 17.1 \\
\hline Arizona & 10.73 & 1.04 & & 10.7 & & & & & & \\
\hline Arkansas & 9.14 & 0.89 & & & 9.1 & & & & & \\
\hline California & 14.74 & 1.44 & & & 14.7 & & & & & \\
\hline Colorado & 10.00 & 0.97 & & & & & 10.0 & & & \\
\hline Connecticut & 20.33 & 1.98 & & & & & 20.3 & & & \\
\hline Delaware & 14.07 & 1.37 & & & & 14.1 & & & & \\
\hline District of Columbia & 13.76 & 1.34 & & & & 13.8 & & & & \\
\hline Florida & 12.39 & 1.21 & & 12.4 & & & & & & \\
\hline Georgia & 10.13 & 0.99 & & & 10.1 & & & & & \\
\hline Hawaii & 24.20 & 2.36 & 24.2 & & & & & & & \\
\hline Idaho & 7.80 & 0.76 & & & & & 7.8 & 7.8 & & \\
\hline Illinois & 11.27 & 1.10 & & & & & 11.3 & & & \\
\hline Indiana & 9.50 & 0.93 & & & & & 9.5 & & & \\
\hline lowa & 9.99 & 0.97 & & & & & 10.0 & 10.0 & & \\
\hline Kansas & 9.53 & 0.93 & & & & 9.5 & & & & \\
\hline Kentucky & 8.37 & 0.81 & & & & 8.4 & & & & \\
\hline Louisiana & 8.10 & 0.79 & & 8.1 & 8.1 & & & & & \\
\hline Maine & 15.65 & 1.52 & & & & & & 15.7 & & \\
\hline Maryland & 14.98 & 1.46 & & & & 15.0 & & & & \\
\hline Massachusetts & 16.87 & 1.64 & & & & & 16.9 & & & \\
\hline Michigan & 11.60 & 1.13 & & & & & 11.6 & 11.6 & & \\
\hline Minnesota & 10.04 & 0.98 & & & & & & 10.0 & 10.0 & \\
\hline Mississippi & 10.22 & 1.00 & & & 10.2 & & & & & \\
\hline Missouri & 8.54 & 0.83 & & & & 8.5 & 8.5 & & & \\
\hline Montana & 8.93 & 0.87 & & & & & & 8.9 & & \\
\hline Nebraska & 8.52 & 0.83 & & & & & 8.5 & & & \\
\hline Nevada & 12.86 & 1.25 & & & 12.9 & & 12.9 & & & \\
\hline New Hampshire & 16.26 & 1.58 & & & & & 16.3 & 16.3 & & \\
\hline New Jersey & 16.31 & 1.59 & & & & 16.3 & 16.3 & & & \\
\hline New Mexico & 10.02 & 0.98 & & & 10.0 & 10.0 & 10.0 & & & \\
\hline New York & 17.50 & 1.70 & & & & & 17.5 & 17.5 & & \\
\hline North Carolina & 9.99 & 0.97 & & & 10.0 & 10.0 & & & & \\
\hline North Dakota & 7.58 & 0.74 & & & & & & 7.6 & 7.6 & \\
\hline Ohio & 10.67 & 1.04 & & & & & 10.7 & & & \\
\hline Oklahoma & 8.49 & 0.83 & & & 8.5 & & & & & \\
\hline Oregon & 8.68 & 0.85 & & & & & 8.7 & & & \\
\hline Pennsylvania & 11.65 & 1.13 & & & & & 11.7 & & & \\
\hline Rhode Island & 15.60 & 1.52 & & & & & 15.6 & & & \\
\hline South Carolina & 10.44 & 1.02 & & & 10.4 & & & & & \\
\hline South Dakota & 8.49 & 0.83 & & & & & & 8.5 & & \\
\hline Tennessee & 9.32 & 0.91 & & & & 9.3 & & & & \\
\hline Texas & 12.38 & 1.21 & & 12.4 & 12.4 & & & & & \\
\hline Utah & 8.48 & 0.83 & & & & & 8.5 & & & \\
\hline Vermont & 14.90 & 1.45 & & & & & & 14.9 & & \\
\hline Virginia & 10.61 & 1.03 & & & & 10.6 & & & & \\
\hline Washington & 7.68 & 0.75 & & & & & 7.7 & & & \\
\hline West Virginia & 7.90 & 0.77 & & & & 7.9 & 7.9 & & & \\
\hline Wisconsin & 11.94 & 1.16 & & & & & & 11.9 & 11.9 & \\
\hline Wyoming & 8.58 & 0.84 & & & & & & 8.6 & & \\
\hline
\end{tabular}


Table 16. Gas Rate Cost Matrix

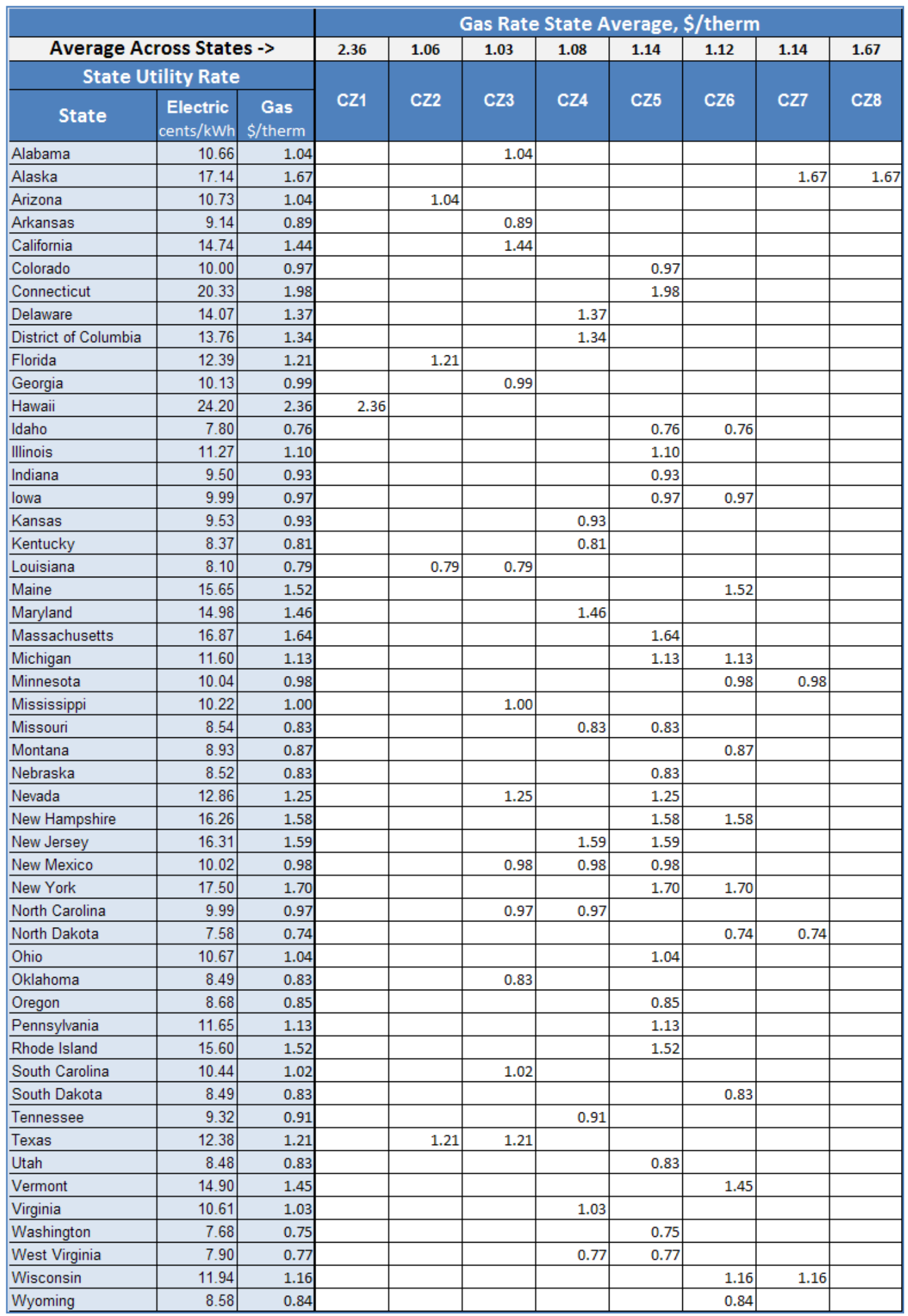




\section{Appendix B: Summary Matrix}

Table 17. Initial Normalized Percent Savings for Electric Fuel and Simulation Location

\begin{tabular}{|c|c|c|c|c|c|c|c|c|c|c|c|c|c|c|c|c|}
\hline Proposed & & $\begin{array}{c}1 \mathrm{~A} \\
\text { hot, humid }\end{array}$ & $\begin{array}{c}2 \mathrm{~A} \\
\text { hot, humid }\end{array}$ & $\begin{array}{c}28 \\
\text { hot, dry }\end{array}$ & $\begin{array}{c}\text { 3A } \\
\text { hot, humid }\end{array}$ & $\begin{array}{c}\text { 3A } \\
\text { hot, humid }\end{array}$ & $\begin{array}{c}38 \\
\text { hot, dry }\end{array}$ & $\begin{array}{c}\text { 4A } \\
\text { mixed, } \\
\text { humidid }\end{array}$ & $\begin{array}{l}\text { 4A } \\
\text { mixed, } \\
\text { humid }\end{array}$ & $\begin{array}{c}4 C \\
\text { marine }\end{array}$ & $\begin{array}{c}\text { 5A } \\
\text { cold, humid }\end{array}$ & $\begin{array}{c}5 B \\
\text { cold, dry }\end{array}$ & $\begin{array}{c}\text { 6A } \\
\text { cold humid }\end{array}$ & $\begin{array}{c}6 \mathrm{~B} \\
\text { cold, dry }\end{array}$ & $\begin{array}{l}7 \\
\text { very cold }\end{array}$ & $\begin{array}{c}8 \\
\text { extreme cold }\end{array}$ \\
\hline $\begin{array}{l}\text { NGES } \\
\text { Section }\end{array}$ & Provision & $\begin{array}{c}\text { Miami, } \\
\text { Florida } \\
\text { Slab } \\
\text { Foundation }\end{array}$ & \begin{tabular}{|c|} 
Houston, \\
Texas \\
Slab \\
Foundation
\end{tabular} & $\begin{array}{c}\text { Phoenix, } \\
\text { Aritona } \\
\text { Slab } \\
\text { Foundation }\end{array}$ & $\begin{array}{c}\text { Allanta, } \\
\text { Georgia } \\
\text { Slab } \\
\text { Foundation }\end{array}$ & $\begin{array}{c}\text { Atlanta, } \\
\text { Georgia } \\
\text { Vented } \\
\text { Crawbspace }\end{array}$ & $\begin{array}{c}\text { Las Vegass, } \\
\text { Nevada } \\
\text { Slab } \\
\text { Foundation }\end{array}$ & $\begin{array}{l}\text { Baltimore, } \\
\text { Maryland } \\
\text { Slab } \\
\text { Foundation }\end{array}$ & $\begin{array}{l}\text { Baltimore, } \\
\text { Maryland } \\
\text { Basement }\end{array}$ & $\begin{array}{c}\text { Seattle, } \\
\text { Washington } \\
\text { Vented } \\
\text { Crawlispace }\end{array}$ & $\begin{array}{l}\text { Chicago, } \\
\text { Mlinois } \\
\text { Basement }\end{array}$ & $\begin{array}{l}\text { Denver, } \\
\text { Colorado } \\
\text { Basement }\end{array}$ & $\begin{array}{c}\text { Minneapolis, } \\
\text { Minnesota } \\
\text { Basement }\end{array}$ & $\begin{array}{l}\text { Helena, } \\
\text { Montana } \\
\text { Basement }\end{array}$ & $\begin{array}{c}\text { Duluth, } \\
\text { Minnesota } \\
\text { Basement }\end{array}$ & $\begin{array}{l}\text { Fairbanks, } \\
\text { Alaska } \\
\text { Slab }\end{array}$ \\
\hline \multicolumn{2}{|r|}{ Ratlo Combined/Indluidual } & 6056 & $65 \%$ & $50 \%$ & $71 \%$ & $70 \%$ & \begin{tabular}{|l|}
$61 \%$ \\
\end{tabular} & $78 \%$ & $76 \%$ & $67 \%$ & $89 \%$ & 885 & 8956 & $90 \%$ & $96 \%$ & $m \%$ \\
\hline \multirow{2}{*}{\multicolumn{2}{|c|}{ Cost Mightight Peccent sunings (individual) }} & 425\% & $46 \%$ & $37 \%$ & $47 \%$ & $45 \%$ & $45 \%$ & $40 \%$ & 445 & 426 & $52 \%$ & $51 \%$ & $50 \%$ & $48 \%$ & $54 \%$ & $66 \%$ \\
\hline & & $\$ 1,889$ & $\$ 1,993$ & $\$ 2,276$ & $\$ 2,254$ & $\$ 2,174$ & $\$ 2,248$ & $\$ 2,607$ & $\$ 2,456$ & $\$ 2,150$ & $\$ 2,862$ & $\$ 2,490$ & $\$ 3,287$ & $\$ 2,976$ & $\$ 4,037$ & $\$ 7,264$ \\
\hline & $\mathrm{coOl}$ & $\$ 702$ & $\$ 427$ & soss & $\$ 232$ & $\$ 241$ & $\$ 457$ & $\$ 159$ & $\$ 145$ & $\$ 24$ & $\$ 89$ & $\$ 92$ & 579 & $\$ 41$ & $\$ 23$ & $\$ 14$ \\
\hline & \begin{tabular}{|l} 
HEAT \\
\end{tabular} & $\$ 32$ & $\$ 388$ & $\$ 240$ & $\$ 792$ & 5696 & $\$ 435$ & $\$ 1,162$ & $\$ 1,015$ & $\$ 840$ & $\$ 1,424$ & $\$ 1,084$ & $\$ 1,806$ & $\$ 1,544$ & $\$ 2,532$ & $\$ \$, 643$ \\
\hline \multirow[t]{5}{*}{703.1 .1} & o to < 5S UA improvement & $0 \times 5$ & os & ON & os & OSA & os & $0 \mathrm{~s}$ & os & ONG & os & $0 \times$ & os & os & os & ox \\
\hline & $5 \%$ to $<10 \mathrm{~K}$ UA improvement & on & $2 \mathrm{~s}$ & $2 \mathrm{~N}$ & $2 \mathrm{~K}$ & $2 \mathrm{~K}$ & 18: & $3 \mathrm{~K}$ & $2 \mathrm{~s}$ & $2 \mathrm{~N}$ & $3 \mathrm{~K}$ & $3 \mathrm{~K}$ & $3 \mathrm{~K}$ & $3 \mathrm{~K}$ & $1 \mathrm{~s}$ & $2 \mathrm{x}$ \\
\hline & $10 \mathrm{~S}$ to $<15 \mathrm{~S}$ UA improvement & on & 45 & $3 \mathrm{k}$ & 45 & 45 & 48 & $6 \mathrm{5}$ & $4 \mathrm{~s}$ & $4 \mathrm{k}$ & 6\% & $6 \mathrm{5}$ & 65 & 65 & $5 \%$ & 55:- \\
\hline & $15 \mathrm{~K}$ to $<20 \mathrm{~S}$ UA improvement & ox & $5 \%$ & $6 \mathrm{~S}$ & 45 & 65 & $6 \%$ & $7 \pi$ & $6 \mathrm{~s}$ & 55 & 85 & $8 \mathrm{~s}$ & $7 \times$ & $7 \pi$ & $6 \mathrm{x}$ & $7 \mathrm{7}$ \\
\hline & $x=20$ S UA improvement & $1 \mathrm{~N}$ & $6 \mathrm{~s}$ & $5 \mathrm{k}$ & $7 \pi$ & $7 \pi$ & $6 \%$ & $2 \pi$ & $9 \%$ & $6 \mathrm{~K}$ & $9 \%$ & $2 \pi$ & $9 \mathrm{~s}$ & $2 \pi$ & $8 \mathrm{~s}$ & $2 \pi$ \\
\hline 703.1 .2 & Insulation installation quality & detary 20095 & thener 2009 & netatry-2009 & edners. 2009 & Indatary 20009 & estever 20009 & netatery 20099 & tedener. 2009 & 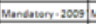 & Uendener-20097 & 4024.2 & Uendever. 2009 & Uencetery 2009 & andater $r 2009$ & Inetart 2009 \\
\hline \multirow{2}{*}{703.1 .3} & Mass walls $76^{\circ}$ & $-1 \mathrm{~K}$ & $-2 \mathrm{k}$ & $-2 \pi$ & $-3 \mathrm{~K}$ & $-3 \times 5$ & $-3 \mathrm{~K}$ & -45 & $-4 \mathrm{~S}$ & $-10 \mathrm{~K}$ & $-14 \mathrm{~K}$ & $-11 \mathrm{k}$ & $-15 \mathrm{k}$ & -145 & $-18 \mathrm{~K}$ & -155 \\
\hline & mass walls $\leq 6^{\prime \prime}$ & $-1 \mathrm{k}$ & -25 & $-2 \mathrm{k}$ & $-3 \mathrm{~K}$ & 705 & -35 & -45 & $-4 \%$ & $-10 \%$ & $-13 \%$ & $-11 \mathrm{k}$ & $-15 \%$ & $-14 \mathrm{~K}$ & $-18 \mathrm{~K}$ & $-15 \mathrm{~s}$ \\
\hline 703.1 .4 & Radiant barrier & $1 \%$ & $1 \%$ & $1 \%$ & $1 \%$ & $0 \%$ & $1 \%$ & $1 \%$ & $0 \%$ & $0 \%$ & $0 \%$ & $0 \%$ & $0 \%$ & 006 & $0 \% 5$ & $1 \%$ \\
\hline \multirow[t]{5}{*}{703.1 .5} & Envelope leakage 5ACH5O & $1 \%$ & 1\% & $1 \%$ & $1 \%$ & $1 \%$ & $1 \%$ & $2 \%$ & $2 \%$ & $2 \%$ & $4 \%$ & $3 \%$ & $4 \%$ & $4 \%$ & $5 \%$ & 5\% \\
\hline & $\triangle A C H 5 O$ & $1 \%$ & $2 \%$ & $1 \%$ & $2 \%$ & $2 \%$ & $2 \%$ & $3 \%$ & $3 \%$ & $3 \%$ & $5 \%$ & $5 \%$ & $7 \%$ & $5 \%$ & $8 \%$ & $8 \%$ \\
\hline & $3 A C H S O$ & $2 \%$ & $2 \%$ & 286 & 3\%. & $3 \%$ & 236 & $4 \%$ & $4 \% 5$ & $4 \%$ & $7 \%$ & $6 \%$ & $9 \%$ & $7 \% 6$ & $10 \%$ & $10 \%$ \\
\hline & $24 \mathrm{CH} 5 \mathrm{O}$ & $2 \%$ & $2 \%$ & $2 \%$ & $4 \%$ & $4 \%$ & $3 \%$ & $5 \%$ & $5 \%$ & $5 \%$ & $8 \%$ & $8 \%$ & $10 \%$ & $8 \%$ & $12 \%$ & $13 \%$ \\
\hline & \begin{tabular}{|l|} 
IACHSO \\
\end{tabular} & $2 \%$ & $3 \%$ & $2 \%$ & $4 \%$ & $4 \%$ & 3\% & $6 \%$ & $6 \%$ & 656 & $8 \%$ & $8 \%$ & $11 \%$ & $8 \%$ & $13 \%$ & $13 \%$ \\
\hline 703.1 .6 .1 & Penestration level 1 & Mandatory & Mandatory & \begin{tabular}{|l|} 
Mandatory \\
\end{tabular} & Mandatory & Mandatory & \begin{tabular}{|l|} 
Mandatory \\
\end{tabular} & \begin{tabular}{|l|} 
Mandatory \\
\end{tabular} & Mandatory & Mandatory & Mandatory & \begin{tabular}{l|l} 
Mandatory & N
\end{tabular} & Mandatory & Mendatory & \begin{tabular}{|l|} 
Mandatory \\
\end{tabular} & Mandatory \\
\hline 703.1.6.2 & Femestration level 2 & $4 \%$ & $1 \%$ & $3 \%$ & $3 \%$ & $3 \%$ & $2 \%$ & $1 \%$ & $1 \%$ & 15 & $2 \%$ & $3 \%$ & $3 \%$ & $3 \%$ & $3 \%$ & $2 \%$ \\
\hline \multirow[t]{2}{*}{703.1 .6 .26} & Femestration level 3 & $5 \%$ & 35 & $45 \%$ & 35 & 36 & 35 & $2 \%$ & 25 & 25 & $4 \%$ & 456 & $5 \%$ & 55 & 55 & $4 \pi$ \\
\hline & Femestration level 4 & None & None & None & None & None & None & 25 & $3 \%$ & $3 \%$ & $4 \%$ & $4 \%$ & $5 \%$ & $4 \%$ & $6 \%$ & $4 \%$ \\
\hline 703.2 .1 & Combo heoting system & $n / 2$ & $N / 2$ & N// & $N / 2$ & $N / A$ & $N / 4$ & N/A & $N=$ & 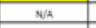 & \begin{tabular}{ll|l|}
$N / 2$ & 1
\end{tabular} & N/A & 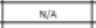 & N/A & 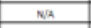 & s//a \\
\hline 703.2 .2 & Furnuce/Bolier efficiency & N/A & $\mathrm{N} / \mathrm{A}$ & N/A & $N / 2$ & N/A & N/A & N/A & N/A & $\mathrm{N} / \mathrm{A}$ & $\mathrm{N} / \mathrm{A}$ & $N / A$ & Nis & $N / A$ & N/A & $N / A$ \\
\hline 703.2 .3 & Boller temperature reset & \begin{tabular}{l|l}
$N / A$ &
\end{tabular} & $N / 4$ & N/A & N/A & $N / A$ & $\mathrm{~N} / \mathrm{A}$ & N/A & $N=$ & N/A & $N / A$ & N/A & $N: A$ & $N / 4$ & 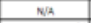 & s/a \\
\hline 703.2 .4 & SEER 14 HSPF8.6 & $2 \%$ & $2 \%$ & $25 \%$ & $3 \%$ & $3 \%$ & $2 \%$ & 450 & $4 \%$ & $3 \%$ & $5 \%$ & $4 \%$ & $5 \%$ & $5 \%$ & $6 \%$ & $6 \%$ \\
\hline 703.2 .5 & SEER 15 HSPF8.8 & $4 \%$ & $3 \%$ & $4 \%$ & $4 \%$ & $4 \%$ & & $5 \%$ & 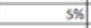 & 366 & $6 \%$ & $5 \%$ & 686 & $6 \%$ & $8 \%$ & $7 \mathrm{ng}$ \\
\hline & SEER 179.0 & $6 \%$ & $5 \%$ & 6\%6 & $5 \%$ & $5 \%$ & 5s: & $68 \%$ & 65: & $4 \%$ & 76 & $6 \%$ & $8 \%$ & 76 & 906 & $9 \%$ \\
\hline & SEER $19 \mathrm{HSPF9.S}$ & 850 & $7 \mathrm{~m}$ & $8 \%$ & $\pi /$ & 760 & $6 \%$ & 886 & 76 & $5 \%$ & $9 \%$ & $8 \% 6$ & $10 \%$ & $9 \%$ & $11 \%$ & $11 \%$ \\
\hline & SEER 21 HSPF10 & 1056 & $8 \%$ & $100 \%$ & $8 \%$ & $8 \% 6$ & $7 \mathrm{~m}$ & $96 \%$ & 996. & $6 \%$ & $11 \%$. & $10 \%$ & $12 \%$ & $11 \%$ & $14 \%$ & $14 \%$ \\
\hline$x 03.25(2)$ & Watersource 1S.0EER 4.0 COP & 76 & 960 & $8 \%$ & $13 \%$ & $12 \%$ & $8 \%$ & $16 \%$ & $15 \%$ & $12 \% 6$ & $20 \%$ & $18 \%$ & 2206 & $21 \%$ & $26 \%$ & 269 \\
\hline 703.2 .6 & GSHP 16.2EER $3.6 \mathrm{COP}$ & $9 \%$ & $9 \%$ & 976 & $12 \% 6$ & $11 \%$ & $8 \%$ & $14 \%$ & $13 \%$ & 1076 & 176 & $15 \%$ & $19 \% 6$ & $18 \%$ & $23 \%$ & 2229 \\
\hline & GSHP 14.1EER $3.3 \mathrm{COP}$ & $6 \%$ & $\mathrm{x}$ & $7 \pi /$ & $9 \%$ & 986 & 68 & $11 \%$ & 115 & $8 \% 6$ & $15 \%$ & $13 \%$ & $16 \%$ & $15 \%$ & 195 & $19 \%$ \\
\hline & GSHP 15 EER $3.5 \mathrm{COP}$ & $7 \times$ & $8 \mathrm{x}$ & 85 & $11 \mathrm{~s}$ & $10 \mathrm{~s}$ & $7 \pi$ & $13 \times$ & $123 \mathrm{~s}$ & $9 \times 0$ & $16 \%$ & $145 \mathrm{~S}$ & $18 \mathrm{x}$ & $17 \%$ & $21 \mathrm{~s}$ & $21 \mathrm{xg}$ \\
\hline & Any type 24 EER 4.3 cop & $14 \mathrm{~s}$ & $13 \mathrm{~s}$ & $15 \times$ & $16 \mathrm{x}$ & $15 \mathrm{~s}$ & $12 \mathrm{x}$ & $18 \times$ & $17 \mathrm{x}$ & $13 \mathrm{~K}$ & $22 \times 4$ & $20 \%$ & $245 \mathrm{~s}$ & $23 \mathrm{~N}$ & 295 & $28 \mathrm{x}$ \\
\hline & Any type 28 EER 4.8 cop & $16 \mathrm{~s}$ & $15 \mathrm{~s}$ & $17 \pi$ & $18 \%$ & $17 x_{0}$ & $14 \times$ & $20 \mathrm{~s}$ & 195 & 145 & $25 \%$ & 2250 & $27 \pi$ & $26 \mathrm{~S}$ & $32 \mathrm{~m}$ & $32 \mathrm{x}$ \\
\hline 703.2 .7 & F*ceilit & & & & & & & & & & & & & & & \\
\hline 703.2 .8 & whole hous. & $2 \mathrm{~s}$ & $1 \mathrm{x}$ & ox & 15.5 & $2 \mathrm{~s}$ & os: & 250 & 285 & 250 & 28. & 280 & 15] & $1 \mathrm{~s}$ & $1 \mathrm{~s}]$ & $1 \mathrm{x}$ \\
\hline 703.2 .9 & Submeter in multiunit & & & & & & & & & & & & & & & \\
\hline 703.2 .10 & Programmable thermostat $70 / 78$ & $1 \mathrm{~s}$ & 18 & 1s: & 18. & $1 \mathrm{~s}$ & 15 & 1s. & $2 \mathrm{~s}$ & $1 \mathrm{~s}$ & $2 \mathrm{~s}$ & $1 \mathrm{~s}$ & $1 \mathrm{~s}$ & $1 \mathrm{~s}$ & 1s & $1 \mathrm{~s}$ \\
\hline 703.3 .1 & Duetless & on & $2 \mathrm{~s}$ & $1 \mathrm{~s}$ & $5 \mathrm{~s}$ & $3 \mathrm{~s}$ & $3 \mathrm{~s}$ & $6 \mathrm{~S}$ & 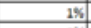 & $5 \%$ & $6 \%$ & $2 \mathrm{~s}$ & $2 \mathrm{x}$ & 15 & $2 \mathrm{~s}$ & $16 \mathrm{~K}$ \\
\hline 703.3 .2 & Ductles & $4 \mathrm{~K}$ & $3 \mathrm{~s}$ & $4 \mathrm{~S}$ & 15. & 15 & $3 \pi$ & $1 \mathrm{~s}$ & 0,5 & $0 \leqslant$ & ox & oN & ON & 05 & $0 \%$ & os \\
\hline 703.3 .3 & Duct installation (interior*) & $5 \pi$ & 58 & 5s & $6 \times 5$ & 45 & 58 & $6 \mathrm{~S}$ & 25 & $6 \mathrm{~S}$ & 25 & $2 \mathrm{~s}$ & $2 \mathrm{~s}$ & 25 & 25 & $16 \times$ \\
\hline 703.3 .4 & Duet leakage $6 \mathrm{~K}$ & $2 \pi$ & \begin{tabular}{|r|}
$8 \mathrm{~K}$ \\
\end{tabular} & 25 & $2 \mathrm{k}$ & 25 & $2 \mathrm{~s}$ & $1 \mathrm{~S}$ & ox & $2 \pi$ & \begin{tabular}{|l|}
$2 \mathrm{k}$ \\
\end{tabular} & 15 & 15 & $0 \leqslant$ & $1 \mathrm{~s}$ & $7 \mathrm{x}$ \\
\hline & $6 \mathrm{~S}$ in & Denotrun 0 & Donotrun & \begin{tabular}{|l|} 
Donotirun \\
\end{tabular} & Donetrun & Donotiun & \begin{tabular}{|l|} 
Denotrun \\
\end{tabular} & \begin{tabular}{|l|} 
Donotirun \\
\end{tabular} & Donetrun & Donotrun 0 & Do notrun & Donotrun 0 & Donotiun & Denotirun & Donotrun & Donotrun \\
\hline & $6 \mathrm{~K}$ both & Do not run $\quad 0$ & Do not run & Do not run & Do not run & Do not run & \begin{tabular}{|l|} 
Do not run \\
\end{tabular} & Do not run & Do not run & Do not run $\mid 0$ & Do not run & Do not run $\quad$ D & Donotrun & Donotrun & Donotrun & Do notrun \\
\hline 703.4 .1 & Water heater energy factor .95 & $1 \%$ & \begin{tabular}{|r|}
$1 \%$ \\
\end{tabular} & \begin{tabular}{|r|}
$1 \%$ \\
\end{tabular} & $1 \%$ & $1 \%$ & \begin{tabular}{|r|}
$1 \%$ \\
\end{tabular} & \begin{tabular}{|r|}
$1 \%$ \\
\end{tabular} & $1 \%$ & $1 \%$ & \begin{tabular}{|r|}
$1 \%$ \\
\end{tabular} & $1 \%$ & $1 \%$ & $1 \%$ & $1 \%$ & $0 \%$ \\
\hline 703.4 .2 & Desuperheater & $8 \%$ & $6 \%$ & $5 \%$ & $4 \%$ & $4 \%$ & $5 \%$ & $4 \%$ & 458 & 286 & $4 \%$ & $4 \%$ & $4 \%$ & $3 \%$ & 3\%. & 200 \\
\hline 703.4 .3 & Drainwate & & & & & & & & & & & & & & & \\
\hline 703.4 .4 & Indirect wat & & & & & & & & & & & & & & & \\
\hline 703.4 .5 & Solar wate & $7 \pi$ & $6 \%$ & $5 \%$ & $6 \%$ & $6 \%$ & $5 \%$ & $5 \%$ & 5\% & $5 \%$ & 55 & $6 \%$ & $5 \%$ & $5 \%$ & $4 \%$ & $2 \pi$ \\
\hline & SEF 1.51 & $9 \%$ & $7 \% 6$ & $6 \%$ & $7 \%$ & $7 \%$ & $6 \%$ & 6 & $7 \%$ & $\pi / 6$ & $\pi$ & $8 \%$ & \% & $7 \%$ & $5 \%$; & 29 \\
\hline & SEF 1.81 & $11 \%$ & $9 \%$ & 76 & $9 \%$ & $9 \%$ & $8 \%$ & $8 \%$ & $9 \%$ & $9 \%$ & $9 \%$ & $10 \% 6$ & $8 \%$ & $9 \%$ & $7 \%$ & 39 \\
\hline & SEF 2.31 & $13 \%$ & $11 \%$ & $9 \%$ & $11 \%$ & $11 \%$ & $9 \%$ & $10 \%$ & $11 \%$ & $11 \%$ & $11 \%$ & $12 \%$ & $96 /$ & $10 \%$ & $8 \%$ & $4 \%$ \\
\hline & SEF 3.01 & $15 \%$ & $13 \%$ & 1056 & $12 \%$ & $13 \%$ & $11 \%$ & $11 \%$ & $12 \%$ & $12 \%$ & $12 \%$ & $14 \%$ & $11 \%$ & $12 \%$ & $9 \%$ & 44: \\
\hline 03.5 .1 & Hardwired lighting $75 \% \mathrm{KE}$ & $2 \%$ & $2 \%$ & $15 \%$ & $1 \%$ & 150 & $1 \%$ & $1 \%$ & $1 \%$ & $15 \%$ & $1 \%$ & $1 \%$ & $1 \%$ & $1 \%$ & $1 \%$ & 0\% \\
\hline & $95 \% \mathrm{HE}$ & $4 \%$ & $3 \%$ & 256 & $2 \%$ & $3 \%$ & $2 \%$ & $25 \%$ & 2\% & $2 \%$ & $2 \%$ & 15 & $2 \%$ & 196 & $1 \%$ & 000 \\
\hline 703.5 .2 & Recessed & & & & & & N/A & N/A & $N / A$ & N/A & $\mathrm{N} / \mathrm{A}$ & $\mathrm{N} / \mathrm{A}$ & N/A & N/A & N/A & N/A \\
\hline 703.5 .3 & E* appliances - Refrig & $1 \%$ & $1 \%$ & ${ }_{15 \%}$ & $0 \%$ & $15 \%$ & 18 & 15 & $1 \%$ & $0 \%$ & $0 \%$ & 15 & 18 & $2 \%$ & o\% & 04 \\
\hline & ow & 05 & $0 \%$ & $0 \%$ & $0 \%$ & 0046 & $0 \%$ & 0.56 & का & $0 \%$ & $0 \%$ & $0 \%$ & $0 \%$ & $1 \%$ & $0 \%$ a & 영 \\
\hline & Washing Mach & of & on & $0 \%$ & o & $0 \% 6$ & 006 & $0 \% 6$ & 006 & 056 & $00 \%$ & $0 \%$ & 006 & $0 \%$ & or & 0\%4 \\
\hline 703.5 .4 & induction cooktop & $0 \%$ & $.1 \%$ & $0 \%$ & .16 & $.2 \%$ & .16 & $0 \%$ & 206 & $0 \%$ & $0 \% 6$ & $0 \%$ & $-1 \%$ & $0 \% 6$ & $006 \mathrm{~s}$ & $0 \pi x$ \\
\hline 703.6 .1 & Passive solar design & $5 \%$ & $4 \%$ & $4 \%$ & 36 & 3\% & 906 & $26 \%$ & 206 & 266 & $3 \%$ & $3 \%$ & $3 \%$ & $4 \%$ & 3\%6 & $0 \%$ \\
\hline 203.6 .2 & Window shading (active) h/c & & & & & & 1.70 & & & & code $85 / .70 \mathrm{c}$ & code $.85 / .70 \mathrm{c}$ & code $.85 \%$ & $\operatorname{code} .855 .70$ & code $85 / .70$ & $\operatorname{code} .85 / .20$ \\
\hline 703.6 .3 & Passive cooling design & $0 \% 6$ & 16 & $1 \%$ & ox & $0 \% 6$ & $8 \%$ & $0 \% 6$ & 0,06 & $0 \% 6$ & 006 & $0 \% 6$ & 006 & $0 \%$ & 006 & -10 \\
\hline 703.6 .4 & Passive heating (mass) & 556 & $4 \%$ & $5 \%$ & $4 \%$ & $5 \%$ & $9 \%$ & $2 \%$ & $3 \% 6$ & $2 \%$ & $00 \%$ & 366 & 266 & $3 \%$ & 266 & $0 \%$ \\
\hline
\end{tabular}


Table 18. Initial Normalized Percent Savings for Gas Fuel and Simulation Location

\begin{tabular}{|c|c|c|c|c|c|c|c|c|c|c|c|c|c|c|c|c|}
\hline Proposed & & hot, humid & hot, humid & $\begin{array}{c}28 \\
\text { hot, dry }\end{array}$ & $\begin{array}{c}\text { 3A } \\
\text { hot, humid }\end{array}$ & $\begin{array}{c}\text { 3A Crawl } \\
\text { hot, humid }\end{array}$ & $\begin{array}{l}\text { 3B slab } \\
\text { hot, dry }\end{array}$ & $\begin{array}{l}\text { 4A } \\
\text { mixed, } \\
\text { humid }\end{array}$ & $\begin{array}{l}\text { 4A } \\
\text { mixed, } \\
\text { humid }\end{array}$ & $\begin{array}{c}4 c \\
\text { marine }\end{array}$ & $\begin{array}{c}\text { 5A } \\
\text { cold, humid }\end{array}$ & $\begin{array}{c}\text { SB } \\
\text { cold, dry }\end{array}$ & $\begin{array}{c}\text { GA } \\
\text { cold humid }\end{array}$ & $\begin{array}{c}6 \mathrm{~B} \\
\text { cold, dry }\end{array}$ & $\stackrel{7}{7}$ & $\begin{array}{c}8 \\
\text { extreme cold }\end{array}$ \\
\hline $\begin{array}{l}\text { NGEs } \\
\text { Section }\end{array}$ & Provision & \begin{tabular}{|c|} 
Miami, \\
Florida \\
Slab \\
Foundation \\
\end{tabular} & $\begin{array}{c}\text { Mouston, } \\
\text { Texas } \\
\text { Slab } \\
\text { Foundation }\end{array}$ & $\begin{array}{c}\begin{array}{c}\text { Phoenix, } \\
\text { Anizona } \\
\text { Slab } \\
\text { Foundation }\end{array} \\
\end{array}$ & 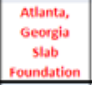 & \begin{tabular}{|c|} 
Atiantar \\
Georgia \\
Vented \\
Crawlspace \\
\end{tabular} & \begin{tabular}{|c|} 
Las Vegas, \\
Nevoda \\
Slab \\
Foundation \\
\end{tabular} & $\begin{array}{c}\text { Baltimore, } \\
\text { Maryland } \\
\text { Slab } \\
\text { Foundation }\end{array}$ & $\begin{array}{l}\text { Baltimore, } \\
\text { Maryland } \\
\text { Basement }\end{array}$ & \begin{tabular}{|c|} 
Seattle, \\
Washington \\
Vented \\
Crawlspace \\
\end{tabular} & $\begin{array}{l}\text { Chicago, } \\
\text { Ilinois } \\
\text { Basement }\end{array}$ & $\begin{array}{l}\text { Denver, } \\
\text { Colorado } \\
\text { Basement }\end{array}$ & $\begin{array}{c}\text { Minneapolits, } \\
\text { Minnesota } \\
\text { Basement }\end{array}$ & $\begin{array}{l}\text { Helena, } \\
\text { Montana } \\
\text { Basement }\end{array}$ & $\begin{array}{c}\text { Duluth, } \\
\text { Minnesota } \\
\text { Basement }\end{array}$ & $\begin{array}{l}\text { Fairbanks. } \\
\text { Aluska } \\
\text { Slab }\end{array}$ \\
\hline \multicolumn{2}{|c|}{ Ratio Combined/Individual } & $86 \%$ & $47 \%$ & $79 \%$ & $77 \%$ & $77 \%$ & \begin{tabular}{|c|}
806 \\
\end{tabular} & 696 & 716 & $73 \%$ & $72 \%$ & $90 \%$ & $71 \mathrm{~K}$ & $76 \%$ & 533 & $63 \%$ \\
\hline \multirow{2}{*}{\multicolumn{2}{|c|}{ 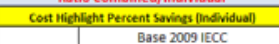 }} & $46 \%$ & $46 \mathrm{X}$ & 405 & 496 & $45 \%$ & $47 \times$ & $42 \times$ & $39 \mathrm{x}$ & $40 \%$ & $37 \times$ & $41 \%$ & 365 & $36 \times$ & $39 \%$ & 435 \\
\hline & & 1,759 & 1,974 & 2,123 & 2,125 & 2,031 & 2,146 & 2,412 & 2,258 & 1,971 & 2,504 & 2,191 & 2,767 & 2,540 & 3,132 & 4,352 \\
\hline GASE & COOLS & 520 & 442 & 816 & 224 & 235 & 505 & 166 & 144 & 17 & 82 & 84 & 71 & 32 & 15 & 5 \\
\hline BASE & HEATS & 12 & $4 \pi$ & 276 & 894 & 705 & 619 & 1,218 & 1,084 & 348 & 1,374 & 1,074 & 1,627 & 1,451 & 2,021 & 3,185 \\
\hline 703.1 .1 & o to $5 \%$ UA improvement" & $0 \%$ & $2 \%$ & $0 \%$ & $0 \% 5$ & $0 \%$ & $0 \%$ & $0 \% 6$ & $0 \%$ & $-1 \%$ & $0 \%$ & $0 \%$ & $0 \%$ & $0 \%$ & $0 \%$ & $0 \%$ \\
\hline & $5 \%$ to $<10 \%$ UA improvement & $0 \% 6$ & $4 \%$ & .286 & $.2 \%$ & $-2 \%$ & $.26 \%$ & $3 \%$ & .18 & $3 \%$ & $3 \%$ & $45 \%$ & $2 \%$ & $3 \%$ & $26 \%$ & $2 \pi$ \\
\hline & $10 \%$ to $<15 \%$ UA improvement & 086 & $5 \%$ & $1 \%$ & $1 \%$ & 150 & $1 \%$ & $5 \%$ & $2 \%$ & $5 \%$ & $5 \%$ & $7 \%$ & $5 \%$ & $6 \%$ & $4 \% 6$ & $4 \%$ \\
\hline & $15 \%$ to $<20 \%$ UA improvement & $0 \%$ & $6 \%$ & 396 & $3 \%$ & $3 \%$ & $10 \%$ & $7 \times 0$ & $6 \%$ & $7 \%$ & $7 \%$ & $9 \%$ & $6 \%$ & $7 \%$ & $5 \%$ & 5\% \\
\hline & $x=20 \% \%$ UA improvement & $1 \%$ & $6 \%$ & $10 \%$ & $10 \%$ & $8 \%$ & $11 \%$ & 996 & $8 \%$ & $8 \%$ & $8 \%$ & $10 \%$ & $8 \%$ & 9\% & $6 \%$ & $6 \%$ \\
\hline 703.1 .2 & Insulation installation quality & neastory 2009 & Uandancer 2009 & Mansatory-2005 & Mandanoer 2009 & Mansatory-2003 & Mandmarr-2009 & Mansatory-2005 & uretanior 2009 , & Mansatory-2003 & Mandaner.2009 & Manostory-2005, & Mandan:ary 2009 & Manantory-2003 & Mardinior, 2009 , & Manatatery-2009 \\
\hline 703.1 .3 & Mass walls $>6^{\prime \prime}$ & $-2 \%$ & $1 \%$ & $-3 \%$ & $-4 \%$ & $-4 \%$ & \begin{tabular}{|r|}
$-4 \%$ \\
\end{tabular} & $.5 \%$ & \begin{tabular}{|r|}
$.5 \%$ \\
\end{tabular} & $-13 \%$ & \begin{tabular}{|l|}
$.12 \%$ \\
\end{tabular} & $-13 \%$ & $.12 \%$ & $-13 \%$ & $.10 \%$ & $-12 \%$ \\
\hline & mass walls $\leq 6^{\prime \prime}$ & $.2 \%$ & $1 \%$ & $.35 \%$ & $.4 \%$ & $-4 \%$ & $.4 \%$ & $-5 \%$ & $.5 \%$ & $.13 \%$ & $.11 \%$ & $.13 \%$ & $.12 \%$ & $-13 \%$ & $.10 \%$ & $.11 \%$ \\
\hline 703.1 .4 & Radiant bumrier & $1 \%$ & $3 \%$ & $1 \%$ & $1 \%$ & $0 \%$ & $1 \%$ & $0 \%$ & $0 \%$ & $0 \%$ & $0 \%$ & $0 \%$ & $0 \%$ & $0 \%$ & $0 \%$ & $0 \%$ \\
\hline 703.1 .5 & Envelope leakage SACHSO & 156 & 35 & $15 \%$ & $2 \%$ & $2 \%$ & $2 \%$ & $25 \%$ & $2 \%$ & 35 & 35 & $3 \%$ & $4 \%$ & $3 \%$ & 35 & $4 \pi$ \\
\hline & AACHSO & $1 \%$ & $4 \%$ & $25 \%$ & $3 \mathrm{~s}$ & $3 \%$ & $3 \%$ & $4 \%$ & 45 & $4 \%$ & $5 \%$ & $5 \%$ & $6 \%$ & $5 \%$ & $5 \%$ & $6 \%$ \\
\hline & $3 \mathrm{ACHSO}$ & $2 \%$ & $4 \%$ & 396 & $4 \%$ & $4 \%$ & $3 \%$ & $5 \%$ & $5 \%$ & $5 \%$ & $6 \%$ & $6 \%$ & $8 \%$ & $7 \%$ & $6 \%$ & 890 \\
\hline & $2 \mathrm{ACHSO}$ & $2 \%$ & $4 \%$ & $3 \%$ & $5 \%$ & $5 \%$ & $4 \%$ & $6 \%$ & $6 \%$ & $6 \%$ & 76 & 896 & $9 \%$ & $8 \%$ & $8 \%$ & $10 \%$ \\
\hline & 1ACHSO & $25 \%$ & $1 \%$ & $3 \%$ & $5 \%$ & $5 \%$ & $5 \%$ & $6 \%$ & $6 \%$ & $7 \%$ & $8 \%$ & $8 \%$ & $10 \%$ & $9 \%$ & $9 \%$ & $11 \%$ \\
\hline 703.1 .6 .1 & Mandatory & Mandatory & Mandatory & \begin{tabular}{|l|} 
Mandstory \\
\end{tabular} & Mandatory & Mandatory & \begin{tabular}{|l|} 
Mandatory \\
\end{tabular} & \begin{tabular}{|l|} 
Mandstory \\
\end{tabular} & Mandatory & Mandstory & \begin{tabular}{|l|} 
Mandatory \\
\end{tabular} & Mandatory & Mandatory & Mandatory & Mandatory & Mandutory \\
\hline 703.1 .6 .2 & Fenestration level 2 & $6 \%$ & $5 \%$ & $1 \%$ & $2 \%$ & $5 \%$ & $4 \%$ & $1 \%$ & \begin{tabular}{|l|}
$1 \%$ \\
\end{tabular} & $1 \%$ & \begin{tabular}{|l|}
$1 \%$ \\
\end{tabular} & $3 \%$ & $2 \%$ & $3 \%$ & $2 \%$ & $2 \%$ \\
\hline $703.1 .6 .2 b$ & Fenestration level 3 & 76 & 686 & $4 \%$ & $6 \%$ & $6 \%$ & 556 & 286 & $2 \%$ & $3 \%$ & $3 \%$ & $5 \%$ & $4 \%$ & $4 \%$ & $3 \%$ & $3 \%$ \\
\hline & Fenestration level 4 & None & None & None & None & None & N/A & 376 & 365 & $4 \%$ & $4 \%$ & $5 \%$ & $4 \%$ & $4 \%$ & 360 & $3 \pi$ \\
\hline 703.2 .1 & Combo heating system & & & & & & & & & & & & & & & \\
\hline $703.2 .2(3)$ & Gas Boiler $\geq 85 \%$ & $0 \% 6$ & $6 \%$ & 396 & $9 \%$ & $8 \%$ & 76 & $11 \%$ & 76 & $11 \%$ & $8 \%$ & 9\% & $8 \%$ & $8 \%$ & 665 & $13 \%$ \\
\hline & Gas Boller $290 \% 6$ & $0 \% 6$ & $6 \%$ & $3 \% 6$ & 1006 & $8 \%$ & $8 \%$ & $11 \%$ & 76 & $11 \%$ & $8 \%$ & $10 \%$ & $8 \%$ & $8 \%$ & 76 & $14 \%$ \\
\hline & Gas Boiler ?94\% & $0 \% 6$ & $6 \%$ & $4 \%$ & $10 \%$ & $9 \%$ & $8 \%$ & $12 \% 6$ & $8 \%$ & $12 \%$ & $8 \%$ & $10 \%$ & 996 & $9 \%$ & 70 & $14 \pi /$ \\
\hline & Gas Boller 296\% & $0 \%$ & $6 \%$ & $4 \%$ & 1066 & $9 \%$ & $8 \%$ & 1266 & 876 & 126 & $9 \%$ & 106\% & $9 \%$ & $9 \%$ & 76 & $15 \%$ \\
\hline 703.2 .3 & Boiler temperature reset & & & & & & & & & & & & & & & \\
\hline $703.2 .2(1)$ & Gas Heater $290 \%$ & $0 \%$ & 456 & $1 \%$ & $3 \%$ & $3 \%$ & 250 & $4 \%$ & $4 \%$ & $4 \%$ & $4 \%$ & $5 \%$ & $5 \%$ & $5 \%$ & $4 \%$ & 5s/ \\
\hline & Gas Heater $2928 \%$ & os & $45 \times$ & 15 & 450 & $4 \times 5$ & $3 \mathrm{x}$ & $5 \mathrm{~s}$ & 5s: & $5 \mathrm{~N}-$ & $5 \times \mathrm{s}$ & $6 \times 5$ & 65 & 65 & 35: & $6 \mathrm{~S}$ \\
\hline & Gas Heater X94: & ONG & $48 \mathrm{~s}$ & 15: & $5 \mathrm{~s}$ & $4 \mathrm{~s}$ & $3 \mathrm{~N}$ & $5 \mathrm{~N}$ & 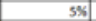 & $5 \mathrm{~N}$ & $6 \mathrm{~S}$ & 786 & $6 \%$ & $6 \mathrm{~S}$ & $5 \times \mathrm{x}$ & $7 \pi$ \\
\hline & Gas Heater $296 \mathrm{~S}$ & $\mathrm{ON}$ & $4 \mathrm{~s}$ & 250 & $6 \%$ & 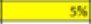 & $4 \times 5$ & $6 \mathrm{~S}$ & $5 s$ & $6 \times 5$ & $7 \times$ & $7 x$ & $7 \pi$ & $7 \pi$ & $6 \times 5$ & $8 \mathrm{x}$ \\
\hline & Gas Heater $\geq 98 \mathrm{~S}$ & oN & $58 \mathrm{~s}$ & 250 & $6 \mathrm{~s}$ & $5 \mathrm{~N}$ & $4 \mathrm{~s}$ & $7 \pi$ & $6 \times$ & $6 \times$ & $7 \pi$ & $8 \times$ & $8 \mathrm{~s}$ & $7 \pi$ & $6 \%$ & 9xd \\
\hline $703.2 .2(2)$ & oil Furnace 85\% & $.1 \mathrm{~s}$ & $-4 \mathrm{~s} /$ & $-6 \mathrm{~S}$ & $.235 \mathrm{~s}$ & -210 & $.16 \mathrm{~s}$ & $.25 \mathrm{~N}$ & $.24 \mathrm{~s}$ & $.25 \mathrm{~s}$ & $.28 \mathrm{~s}$ & $.31 \mathrm{~N}$ & .305 & .318 & .2456 & $.33 \mathrm{~N}$ \\
\hline & Oil Furnace 90\% & $.1 \mathrm{~s}$ & $.3 \times 5$ & $-5 \mathrm{~s}$ & .2050 & $-18 \mathrm{~S}$ & $-14 \times$ & $.21 \mathrm{~s}$ & $.21 \mathrm{~s}$ & $.21 \mathrm{~s}$ & .245 & $.27 \pi$ & $.25 \mathrm{~K}$ & $.26 \mathrm{~K}$ & $.21 \mathrm{~s}$ & $.28 \mathrm{~S}$ \\
\hline $703.2 .2(4)$ & oil Boil 85s: & $.1 \mathrm{~s}$ & os & $.1 \mathrm{~s}$ & .956 & .105 & $.6 \mathrm{~N}$ & $.9 \mathrm{~N}$ & $.15 \mathrm{~s}$ & $.9 \%$ & $.185 \mathrm{~s}$ & $.19 \mathrm{~N}$ & .2005 & $.21 \mathrm{~s}$ & $-16 \mathrm{~s}$ & $.14 \mathrm{~s}$ \\
\hline & oil Boiler 90S & os: & OS: & $-1 \mathrm{~s}$ & $-105 /$ & -1055 & $-6 \mathrm{x}$ & $-10 \mathrm{~s}$ & $.16 \mathrm{x}$ & $.10 \times 5$ & $.19 \mathrm{~A}$ & $.20 \mathrm{~N}$ & $.21 \%$ & $.21 \mathrm{No}$ & . $17 \mathrm{x}$ & $-15 \mathrm{~N}$ \\
\hline $703.2 .5(1)$ & SEER 14 EER11.5 & 25 & $1 \mathrm{~s}$ & 28 & $1 \mathrm{~s}$ & 15 & 15] & $0 \mathrm{OS}$ & os & $0 \times 0$ & OSA & ost & os & $0 \%$ & $0 \times$ & ox \\
\hline & SEER 15 EER12.5 & $3 \mathrm{~K}$ & $2 \mathrm{~s}$ & $4 \mathrm{~K}$ & $2 \mathrm{~s}$ & $1 \mathrm{~K}$ & $3 \mathrm{~K}$ & $1 \mathrm{~N}$ & $1 \mathrm{k}$ & ONG & OS & ON & OK & ON & ON & osf \\
\hline & SELR 17 EER12.5 & $6 \pi$ & 28 & $7 \pi$ & $2 \%$ & 25 & $4 \mathrm{~S}$ & 15 & 15 & 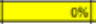 & 15 & $1 \mathrm{~s}$ & ox & OSt & Os: & os \\
\hline & SEER 19 EER12.5 & 85 & $3 \mathrm{~s}$ & 105 & $3 \mathrm{~K}$ & $3 \mathrm{~s}$ & 65 & 25 & $1 \mathrm{~s}$ & ON & 15 & 1s: & $1 \mathrm{~s}$ & $0 \leqslant$ & or & os \\
\hline & SEER 21 EER12.5 & 1050 & 45. & $12 \pi$ & $3 \mathrm{k}$ & $3 \mathrm{~S}$ & 76 & 28 & $2 \pi$ & $0 \%$ & 18 & 15 & 15 & $0 \leqslant$ & ox & 0 os \\
\hline 703.2 .6 & GSHP & & & & & & & & & & 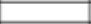 & & & & + & \\
\hline 703.2 .7 & E" ceiling tans & & & & & & & & & & & & & & & \\
\hline 703.2 .8 & ventilation fan & $3 \mathrm{~N}$ & os & $0 \mathrm{OS}$ & $1 \mathrm{~s}$ & $1 \mathrm{~s}$ & os & 25 & $2 \sqrt{6}$ & $3 \mathrm{~K}$ & $2 \mathrm{~s}$ & $3 \mathrm{~S}$ & $2 \mathrm{k}$ & $2 \mathrm{~K}$ & $2 \mathrm{~s}$ & $2 \pi$ \\
\hline 703.2 .9 & Submeter in multiunit & & & & & & & & & & & & & & & \\
\hline 703.2 .10 & Programmable thermostat $70 / 78$ & 15 & OS & 1S: & 15 & 18 & 15: & 15. & $1 \mathrm{w}$ & $1 \mathrm{~s}$ & 15: & 15. & 15 & 15 & $1 \mathrm{~s}$ & 18 \\
\hline 703.3 .1 & Ductless heating system & OK & $3 \mathrm{~K}$ & $2 \pi$ & $5 \%$ & $3 \mathrm{~K}$ & $3 \mathrm{k}$ & $6 \mathrm{~S}$ & $1 \mathrm{~s}$ & $5 \%$ & 26 & $2 \mathrm{~N}$ & $2 \mathrm{k}$ & $2 \mathrm{k}$ & $1 \mathrm{~s}$ & $7 \pi$ \\
\hline 703.3 .2 & Ductless cooling system & $6 \%$ & $3 \%$ & $5 \%$ & $1 \%$ & 180 & $3 \%$ & $1 \%$ & $0 \%$ & 086 & $0 \%$ & 086 & $0 \%$ & $0 \%$ & $0 \% 5$ & 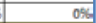 \\
\hline 703.3 .3 & Duct installation (interior*) & $6 \%$ & 6\%: & $7 \%$ & $6 \%$ & $4 \%$ & $6 \%$ & $7 \%$ & $26 \%$ & $5 \%$ & $2 \%$ & $2 \%$ & 250 & 258 & $13 \%$ & $13 \mathrm{~N}$ \\
\hline 703.3 .4 & Duct leakage $6 \%$ & $3 \%$ & $4 \%$ & 346 & $2 \%$ & $2 \%$ & $3 \%$ & $2 \%$ & $1 \%$ & 296 & $1 \%$ & $1 \%$ & $1 \%$ & $1 \%$ & $1 \%$ & $2 \pi 0$ \\
\hline & $6 \%$ in & \begin{tabular}{|l|l} 
Do not run & 0 \\
\end{tabular} & Do not run & Donot run & Do not run & Donot run & Do not run & Do not run & Do not run & Do not run & Do not run & & & & & \\
\hline & $6 \%$ both & Do not run & Donot run & Do not run & Do not run & Do not run & Do not run & Donot run & Do not run & Do not run & Do not run & & & & & \\
\hline 703.4 .1 & Water heate & $1 \%$ & $3 \%$ & $1 \%$ & $1 \%$ & $1 \%$ & $1 \%$ & \begin{tabular}{|l|}
$0 \%$ \\
\end{tabular} & $1 \%$ & $1 \%$ & $0 \%$ & $1 \%$ & $0 \%$ & $0 \%$ & $0 \%$ & 006 \\
\hline & Tankless > 200K Dtuh TE $82 \%$ & $3 \%$ & $4 \%$ & $2 \%$ & $2 \%$ & $2 \%$ & $2 \%$ & $2 \%$ & $2 \%$ & $4 \%$ & $2 \%$ & $2 \%$ & $1 \%$ & $28 \%$ & $1 \%$ & 196 \\
\hline & Tankless 86\% plus & $3 \%$ & $4 \%$ & $2 \%$ & $2 \%$ & $3 \%$ & 3\% & $28 \%$ & $2 \%$ & $4 \%$ & $2 \%$ & $3 \%$ & $25 \%$ & 250 & $1 \%$ & 19. \\
\hline 703.4 .2 & Desuperheater & & & & & & & & & & & & & & & \\
\hline 703.4 .3 & Drainwater heat recovery & & & & & & & & & & & & & & & \\
\hline 703.4 .4 & Indirest w & & & & & & & & & & & & & & & \\
\hline 703.4 .5 & Solar water heater SEF 1.3 & $8 \%$ & $45 \%$ & 65 & $6 \%$ & $6 \%$ & $6 \%$ & $5 \%$ & $5 \%$ & $6 \%$ & $5 \%$ & $7 \%$ & $4 \%$ & $5 \%$ & 36 & $2 \mathrm{~s}$ \\
\hline & SEF 1.51 & $9 \%$ & $45 /$ & 756 & 70 & $7 \%$ & $7 \%$ & $5 \%$ & $6 \%$ & $7 \%$ & $5 \%$ & $9 \%$ & $5 \%$ & $5 \%$ & 35 & 3\% \\
\hline & SEF 1.81 & 1056 & $5 \%$ & $7 \%$ & $7 \mathrm{~m}$ & $8 \%$ & 78 & $6 \%$ & $6 \%$ & 780 & $6 \%$ & $12 \%$ & $5 \%$ & $6 \%$ & $3 \%$ & 394 \\
\hline & SEF 2.31 & $11 \%$ & $5 \%$ & $85 \%$ & $8 \%$ & 856 & $8 \%$ & $6 \%$ & $\mathrm{Am}$ & $8 \%$ & $6 \%$ & $14 \%$ & $6 \%$ & $7 \%$ & 4\%: & 3\% \\
\hline & SEF 3.01 & $12 \%$ & 69 & $95 \%$ & $9 \%$ & $9 \%$ & $9 \%$ & $\pi / \%$ & $8 \%$ & $9 \%$ & $7 \%$ & $16 \%$ & $6 \%$ & 760 & $4 \%$ & 4\% \\
\hline 703.5 .1 & Mardwired lighting $75 \%$ HE & $3 \%$ & $4 \% 6$ & $25 \%$ & 26 & $2 \%$ & $2 \%$ & $1 \%$ & $1 \%$ & $1 \%$ & 18 & $2 \%$ & $1 \%$ & $1 \%$ & $16 \mathrm{6}$ & 16 \\
\hline & $95 \% \mathrm{HE}$ & $5 \%$ & $4 \%$ & $35 \%$ & $3 \%$ & 3\% & 3\% & $2 \%$ & $2 \%$ & 256 & $2 \%$ & $3 \%$ & $2 \%$ & $2 \%$ & 16 & 1ब \\
\hline 203.52 & Recessed lighting & & & & & & & & & & & & & & & \\
\hline 703.5 .3 & E" appliances-Refrig & $2 \%$ & $3 \%$ & $1 \%$ & $1 \%$ & $1 \%$ & $15 \mathrm{a}$ & 186 & $1 \%$ & $0 \%$ & $16 \mathrm{~s}$ & $1 \%$ & 196 & 156 & oses & ond \\
\hline & ow & $0 \%$ & $3 \% 6$ & 0 & 0 & 0 & $0 \% 6$ & $0 \% 6$ & 006 & $0 \% 6$ & $0 \% \mathrm{~s}$ & $0 \% 6$ & 006 & $0 \% 5$ & ox & ong \\
\hline & Washing & $0 \% 6$ & 366 & 086 & $0 \%$ & $0 \% 6$ & $0 \% \mathrm{~s}$ & $0 \% 6$ & ons & $2 \%$ & os & $0 \%$ & 006 & $0 \% 6$ & 006 & $0 \%$ \\
\hline 703.5 .4 & Induction cooktop & $-1 \%$ & 206 & 086 & -196 & $-1 \%$ & .16 & $0 \% 6$ & $.1 \%$ & $2 \%$ & Oof & $-1 \%$ & OOS & $-1 \%$ & of & ons \\
\hline 703.6 .1 & passive solar design & 766 & $3 \%$ & 76 & $4 \%$ & $4 \%$ & $5 \%$ & 286 & 206 & $3 \%$ & 26 & $4 \%$ & $3 \%$ & $3 \%$ & 206 & 220 \\
\hline 6.2 & Window & $702000 \mathrm{cos} 0 \mathrm{a}$ & 20200050000 & $702000 \cos \theta$ & 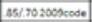 & 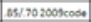 & as/70 2000scode & b5/70:00060006 & |45/70:700500006. & 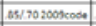 & 45/7002006coded & 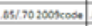 & $405 / 7020$ & $005 / 7020$ & $08 / 7020$ & as/ $70: 0006 \mathrm{kos}$ \\
\hline 703.6 .3 & Passive cooling design & $3 \%$ & $0 \% 6$ & $1 \%$ & $0 \%$ & $0 \%$ & $0 \%$ & $0 \%$ & $1 \%$ & $0 \%$ & 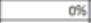 & $0 \%$ & os & $0 \% 6$ & 006 & $1 \mathrm{~s}$ \\
\hline 703.6 .4 & Passive hesting (mass) & $6 \%$ & 486 & 76 & $5 \%$ & $6 \%$ & $6 \%$ & $2 \%$ & 336 & $2 \%$ & 26 & $5 \%$ & 276 & $3 \%$ & 26 & 100 \\
\hline
\end{tabular}




\section{U.S. DEPARTMENT OF Energy Efficiency \& ENERY Renewable Energy}

